\title{
IMAGES OF KINGS OF ADIABENE: NUMISMATIC AND SCULPTURAL EVIDENCE
}

\author{
By Michą MARCIAK AND ROBERT S. WÓJCIKOWSKI ${ }^{1}$
}

\begin{abstract}
This paper offers the first ever discussion of all extant images of Abdissar, Monobazos I and 'tlw (Attalos), Kings of Adiabene. In analysing the numismatic and sculptural data, a few conclusions on the historical context are suggested. First, it is argued that stylistic features of the coinage of Abdissar suggest a date in the first half of the second century B.C.E., and this dating bears upon the question of the historical origin of the Kingdom of Adiabene. Adiabene originated as one of many "post-Seleucid" states which arose in the Near East when the Seleucid kingdom started to crumble, before the advent of the Parthians. This suggestion is also corroborated by stylistic features of the coinage which accentuate the divine investiture of royal power in Abdissar. It is also held that the Batas-Herir monument depicts King Abdissar. Second, the images on the coin of Monobazos I clearly reflect the time of Adiabene's economic prosperity and political rise to significance among Parthian "lesser kings" in the first half of the first century C.E. Third, the reign of King 'tlw (Attalos) remains largely obscure, but the placement of his sculpture in Hatra clearly shows good political relations and close cultural ties between the kingdoms of Adiabene and Hatra in the first half of the third century C.E. Additionally, the authors argue that the images of Oriental kings on the coins of Septimius Severus do not represent any particular Oriental rulers (of Edessa, Adiabene or Hatra), but are merely stereotypical images of what the Romans considered to be typical Oriental royal outfits.
\end{abstract}

\section{Introduction}

In recent decades there has been a considerable growth of scholarly interest in the frontier area between Imperium Romanum and Imperium Parthicum (and their later successors, Byzantium and the Sasanians). ${ }^{2}$ This interest is no longer limited only to these two great kingdoms, but equally applies to small geopolitical entities, frequently labelled as regna minora. ${ }^{3}$ These kingdoms, located between the West and the East, frequently featured exceedingly interesting culture which escapes any strict labelling, at least in accordance with the so-called "classical" canon. ${ }^{4}$ Often straddling important communication lines including river fords and mountains passes, these kingdoms had some strategic significance on an international level. Ancient sources bring them to our attention most often during accounts of Roman or Parthian/Sasanian campaigns when invading forces had

\footnotetext{
${ }^{1}$ We wish to express our gratitude to all colleagues who contributed to this paper. First of all, we are indebted to Dr J. Reade (University of Copenhagen) and Prof. M.J. Olbrycht (Rzeszów University) for reading our draft and suggesting several valuable improvements. Furthermore, we would like to thank the journal's anonymous reviewer for his (or her) valuable comments. Of course, the sole responsibility for the content of this paper lies with the authors. Several colleagues helped us acquire the photographs necessary for this paper, for which we remain grateful: Prof. M.J. Olbrycht (Rzeszów University), Dr F. de Callataÿ (Bibliothèque royale de Belgique), Dr D. Klose and Prof. K. Ehling (Staatliche Münzsammlung München), Dr J. Bodzek (Jagiellonian University in Kraków), Dr Andrzej Betlej (The National Museum in Kraków), Prof. H. von Gall (Deutsches Archäologisches Institut) and Diane C. Siebrandt, MSc. (Deakin University). Furthermore, we gratefully acknowledge the permission of several institutions to publish photographs from their websites, archives or publications: the Classical Numismatic Group, Inc., Forum Ancient Coins, the Hutten-Czapski Museum in Kraków and Deutsches
}

Archäologisches Institut. Last, but not least, we wish to thank $\mathrm{Mr}$ Bernard Maryniak and $\mathrm{Mr}$ Przemysław Maryniak for their technical help in editing several of our photographs.

${ }^{2}$ To give only a few examples: Ziegler (1964), Wolski (1976), Kettenhofen (1982), Dąbrowa (1983), Dodgeon and Lieu (1991), Olbrycht (1998a), Greatrex and Lieu (2002), Dignas and Winter (2007).

${ }_{3}^{3}$ Pani (1972): Kappadokia, Armenia, Media Atropatene; Schottky (1989): Media-Atropatene and Armenia; Hauser (1998): Hatra; Dirven (1999): Dura-Europos and Palmyra; Schuol (2000): Charakene; Kaizer (2002): Palmyra; Sommer (2003): Hatra; Sommer (2005): Palmyra, Edessa, Dura-Europos and Hatra; Facella (2006): Kommagene; Gawlikowski (2010): Palmyra; Hartmann (2001): Palmyra.

${ }^{4}$ See Canepa (2007), who speaks about Kommagene's material culture and the "Winkelmann canon", and rightly observes that, from the point of view of the Winkelmann canon, the artistic products of Kommagene may appear to be "megalomaniacal curiosities or barbarous departures" from the paradigm. 
to pass through the territory of various vassal kingdoms before finally entering their enemy's heartland. ${ }^{5}$

One such kingdom is Adiabene, a small north-Mesopotamian kingdom which has appeared in recent scholarship in two contexts: the conversion of the Adiabene royalty to Judaism in the first century C.E., ${ }^{6}$ and the Roman-Parthian relationship. ${ }^{7}$ The first topic, mainly explored within the field of Jewish studies, has always created an interest in Adiabene because of the kingdom's connections with Jerusalem. ${ }^{8}$ We know from literary sources that some members of the Adiabene royal family moved to Jerusalem and built several structures there which accounted for most of the city's eye-catching landmarks during the first century C.E.: a magnificent mausoleum crowned with three pyramids (see Josephus, Antiquitates Judaicae, 20.95, De Bello Judaico, 5.55; 5.119; 5.147; Pausanias, Graeciae descriptio, 8.16.4-5; Eusebius of Caesarea, Historia ecclesiastica 2.12.3; and Jerome, Epistulae, 108), and three palaces located in the Lower City of David (see Jos. Bell. 4.567; 5.252; 6.355). Not surprisingly, the alleged discovery of Queen Helena's palace in 2007 by two Israeli archaeologists made the front pages of archaeological news in Israel. ${ }^{9}$

Unlike Jerusalem, the Adiabene region has not produced sensational archaeological discoveries. Our knowledge about Adiabene is based on mainly Greek and Latin historical sources (Strabo, Plutarch, Tacitus, Pliny the Elder, Ptolemy, Cassius Dio and Ammianus Marcellinus), several multi-period archaeological sites (Arbela, Kilizu, Abu Sheetha, Ashur, Nineveh and Nimrud) and some epigraphic and numismatic data from the region (the trilingual inscription of Shapur I on the walls of Ka ba-ye Zardosht near Naqsh-e Rostam, Hatra inscriptions nos. 21, 113, 114; the socalled Natounia coins). Taken together, this information does offer some insight into Adiabene's history and cultural environment, but much remains unknown. ${ }^{10}$ Nevertheless, this situation should not lead historians to cognitive indifference, but rather make them appreciate every source available. In this context, the aim of this paper is to offer the first ever discussion of all extant images of the kings of Adiabene.

\section{Rulers of Hellenistic-Parthian Adiabene}

Thanks to both literary sources and numismatic-epigraphic evidence, we know of the existence of ten rulers of Adiabene in the Hellenistic and Parthian periods. ${ }^{11}$ They are as follows: Abdissar (the first half of the second century B.C.E.); an anonymous king of Adiabene (an ally of Tigranes the Great during the battle at Tigranokerta in 69 в.C.E.); Artaxares (the second half of the first century в.C.E.); Izates I (the second half of the first century B.C.E.); Monobazos I Bazaios (c. 5 B.C.E. -30 C.E.); Izates II (c. 30-55 C.E.); Monobazos II (c. 55-70 C.E.); Mebarsapes (during Trajan's campaigns in the East in $c$. 114-115 C.E.); an anonymous ruler of Adiabene (one of the Eastern supporters of Pescennius Niger, c. 192-194 C.E.); and 'tlw (Attalos, the first half of the third century C.E.). However, only in the case of three rulers, Abdissar, Monobazos I and 'tlw (Attalos), do we possess numismatic and epigraphic evidence that includes images of these rulers.

Abdissar. The earliest image of a king of Adiabene is that of Abdissar. ${ }^{12}$ This king is known to scholarship only through his coinage. He was long considered to be a ruler of Armenia or Sophene

\footnotetext{
${ }^{5}$ See Marciak (2014a: 197).

${ }^{6}$ Adiabene in Jewish context has been the focus of two $\mathrm{PhD}$ theses: Barish (1983) and Marciak (2014a). For the latest state of research, see Marciak (2014a: 15-19).

${ }^{7}$ See Debevoise (1938: 51, 71, 75, 165-78, 196-97, 225-33); Dillemann (1962: 112, 268-72; 276-86); Ziegler (1964: 4596); Colpe (1974: 97-108); Dąbrowa (1983: 118-24); Rajak (1998: 309-24); Wolski (1993: 88-89, 115-16, 126-27, 17980); Olbrycht (1997: 81-100, especially $84-85$ and n. 13); Olbrycht (1998a: 177-78); Olbrycht (1998b: 125-26); Fowler (2010: 72-73); Dąbrowa (2011: 174). Detailed studies on some aspects of Hellenistic-Parthian Adiabene include the following: Delitzsch (1887); Eiland (1998); Reade (1998); Reade (2001); and Marciak (2011: 135-220).
}

\footnotetext{
${ }^{8}$ For a good overview of the literature on this topic, see Vincent and Steve (1954: 235-36) and Bieberstein and Bloedhorn (1994: 397).

${ }^{9}$ Ben-Ami and Tchekhanovetz (2011a); Ben-Ami and Tchekhanovetz (2011b); Marciak (2014a: 166-68); Notley and García (2014).

${ }^{10}$ See Marciak (2014a: 175-266). See also Marciak (2014b).

${ }^{11}$ See Marciak (2014a: 233-46).

${ }^{12}$ Known as A $A \delta \_\sigma \sigma \alpha \rho \circ$ to Lipiński and Abdissarès to de Callataÿ. Yet the name is recorded only in the genitive, and consequently both forms in the Greek nominative are grammatically possible.
} 
by numismatists due to stylistic similarities between his coins and other, roughly speaking, 'Armenian' coins of Kommagene and Sophene. ${ }^{13}$ Edward Lipiński was the first to suggest, on purely linguistic and historical terms, that Abdissar should be identified as a king of Adiabene. ${ }^{14}$ While all known rulers of Sophene bore only Iranian names (it was similar in Kommagene, but Greek names were also used there), Abdissar is a typically Semitic name meaning "the servant of Ishtar" and consisting of two elements: ' $b d$ and 'sr. As Lipiński has pointed out, the name has mainly been attested in areas inhabited by Semitic populations, and the cult of Ishtar has traditionally been strong in the area that once formed the core of the Assyrian state and later the state of Adiabene. The Belgian numismatist Francois de Callatay came forward with a numismatic argument independently of E. Lipiński: ${ }^{15}$ he reinterpreted the legend on one of Abdissar's coins as $[\mathrm{BA} \Sigma] \mathrm{I} \Lambda \mathrm{E}[\Omega \Sigma][\mathrm{AB}] \Delta \mathrm{I} \Sigma \Sigma \mathrm{APOY}[\mathrm{A}] \Delta \mathrm{AIABHNOY} .{ }^{16}$ Of course, the form $[\mathrm{A}] \Delta \mathrm{AIABHNOY}$ is an irregular spelling, but it can be explained in phonetic terms: the Greek $\alpha$ is phonetically

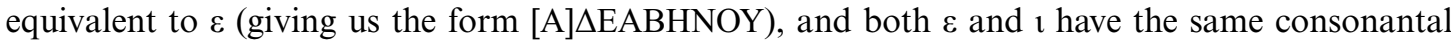
value $[\mathrm{y}]$ before $\alpha$ (as in $[\mathrm{A}] \triangle \mathrm{EABHNOY}$ and [A] $\mathrm{IABHNOY}$ ). As a result, they are both pronounced [ya]. ${ }^{17}$

Nevertheless, the introduction of the term "of Adiabene" on a coin is unusual because, as a rule, Hellenistic royal coinage did not contain any geographical or ethnographical (or political) terms in the genitive, and this novelty certainly requires explanation. According to de Callataÿ, the introduction of this epithet may have served Abdissar by emphasizing his royal prerogatives to Adiabene in a situation of unstable geopolitical conditions (for which the second century B.C.E. certainly offers a good background). ${ }^{18}$ Maciej Grabowski went even further by arguing that the purpose was to announce the introduction of the monarchy in Adiabene. ${ }^{19}$ This intriguing suggestion brings us to the question of how (and when) Adiabene rose to the status of an independent kingdom. ${ }^{20}$

The first literary attestation of a king of Adiabene can be found in Plutarch's description of the battle near Tigranokerta in 69 B.C.E. In his description, an anonymous king of Adiabene appears as an ally of the Armenian king, Tigranes the Great, and the Parthian king, Phraates III (Plut. Luc. 26-29). The incorporation of Adiabene into the Parthian kingdom must have taken place in the second century B.C.E. in the context of the gradual Parthian takeover of Seleucid Mesopotamia. It has been suggested that the territory of Adiabene was directly conquered by Mithradates II (on the basis of Str. 11.14.15) ${ }^{21}$ or Mithradates I ${ }^{22}$ (on the basis of archaeological evidence from Nimrud ${ }^{23}$ : signs of the destruction of level 2 around 145-140 B.C.E.). As the text of Str. 11.14.15 does not speak of any king ruling Adiabene before the Parthian invasion (in fact, the text speaks only about the region of Arbela), one may tentatively suggest that the monarchy in Adiabene came only with the rise of the Parthians in the region, who either elevated a local ruler to the status of a minor king within the Parthian Commonwealth ${ }^{24}$ (see Strabo 16.1.19: Adiabene is "a part of Babylonia, although it has an archon of its own" 25 ) or installed a member of their

\footnotetext{
${ }_{14}^{13}$ Bedoukian (1985: 13).

${ }^{14}$ Lipiński (1982).

${ }^{15}$ There are no references to Lipiński's 1982 publication in de Callataÿ's paper, published in 1996, which most likely means that de Callataÿ was unaware of Lipiński's interpretation.

${ }_{16}$ De Callataÿ (1996).

${ }^{17}$ See Marciak (2014a: 225, n. 58) who owes this explanation to the principle formulated by Tromp (2005: 31 and 35).

${ }^{18}$ De Callataÿ (1996: 140).

${ }^{19}$ Grabowski (2011).

${ }^{20}$ However, we completely disagree with Grabowski's use of terminology including the words indigenous, foreign and ethnic, and reject a purely speculative reconstruction of potential tension between Abdissar and his subjects based on the juxtaposition of the foreign provenance of the former and the indigenous origin of the latter. See Grabowski (2011: 134), who speculates that "obverse designs closely
}

resembling those of earlier Sophenian rulers (to whom Abdissares was apparently related) may have been perceived by indigenous Adiabenian nobility as foreign and thus difficult to accept. Hence the introduction of the term "Adiabenian" to the coinage legends, which should be considered as a propaganda measure aiming to counterbalance the portrait of the ruler represented according to the foreign fashion. This term would thus be important (though in reality false) evidence of the ruler's ethnic origin and cultural affiliation, which were usually the most crucial aspects of legitimisation of a newly acquired royal status".

${ }^{21}$ Dąbrowa (2011: 170).

${ }^{22}$ Hauser (1994: 457, 477)

${ }^{23}$ Oates and Oates (1958: 115-18); Oates (1968: 64); Marciak (2014a: 215)

${ }^{24}$ For this term, see de Jong (2013: 143-60).

${ }^{25}$ This text most likely reflects the late Achaemenid state of affairs. See Jacobs (1994: 65, 147-52, especially p. 150). 
own family or the Parthian nobility in Adiabene. ${ }^{26}$ However, if the coins of Abdissar are to be dated to the first half of the second century B.C.E. (see below), that is, before the Parthian takeover of the region, then the monarchy in Adiabene must have originated within the context of the gradual collapse of the Seleucid suzerainty in Mesopotamia. ${ }^{27}$ Indeed, good parallels for this hypothesis can be found in the history of Greater Armenia, Sophene, Gordyene and Kommagene, where local rulers assumed the titles of the kings when the Seleucids started to lose their grip on much of their former territory in the Near East. ${ }^{28}$

Images of Abdissar, the ruler of Adiabene, appear on three types of coins minted in his name. ${ }^{29}$ The first type displays Abdissar's bust on the obverse (Fig. 1). The king's head is shown facing right, with a short, neatly cropped beard and a very characteristic tiara. Its top is pointed downwards and its neck covers are upturned. It is tied up with a wide headband or diadem with ribbons falling freely down the ruler's back. It is clearly a soft tiara, known as a satrapal tiara, which was worn by satraps of the Achaemenid period. The reverse shows an eagle standing on the ground with closed wings, facing right, and the legend $\mathrm{BA} \Sigma \mathrm{I} \Lambda \mathrm{E} \Omega \Sigma \mathrm{AB} \triangle \mathrm{I} \Sigma \Sigma \mathrm{APOY} .{ }^{30}$ Type II repeats the above pattern with regards to the king and the eagle (Fig. 2). On the reverse, the eagle is shown alongside the legend $\mathrm{BA} \Sigma \mathrm{I} \Lambda \mathrm{E} \Omega \Sigma \mathrm{AB} \Delta \mathrm{I} \Sigma \Sigma \mathrm{APOY}[\mathrm{A}] \triangle \mathrm{AIABHNOY} .{ }^{31}$ Conversely, the third type represents what is evidently a different image (Fig. 3). The obverse displays the same type of image, with the king wearing the tiara, but the reverse depicts a horse's head instead of an eagle. It faces right (just like the king's image), along with the inscription $\mathrm{BA} \Sigma \mathrm{I} \Lambda \mathrm{E} \Omega \Sigma \mathrm{AB} \Delta \mathrm{I} \Sigma \Sigma \mathrm{APOY} .{ }^{32}$

The first known representation of a tiara with the raised and diadem-bound neck coverings, as portrayed on Abdissar's coins, appears on the coinage of Xerxes (Fig. 4), the ruler of Arsamosata in Sophene (late third to the early second century B.C.E.). ${ }^{33}$ A similar tiara also appears on the coin of Baydād, ruler of Fars, i.e., the native part of Persia, in the early second century B.C.E. (Fig. 5). ${ }^{34}$ In this case, the diadem holds down the upturned ear covers, while the neck covering falls freely from the back of the tiara onto the Persian ruler's neck. ${ }^{35}$

A tiara that is similar to the one on Abdissar's coins is worn by the ruler represented on a rock-cut relief at Batas-Herir, located in northern Iraq (Figs. 6-7). ${ }^{36}$ The top of the tiara points downwards and the neck coverings are lifted up. In addition, the tiara also has upturned ear coverings. The relief shows the figure of a man standing with his right hand raised, fist clenched and index finger straight, in a gesture of greeting or adoration. His left arm, hanging freely along the side of his body, holds a long cane tipped with three knobs, most likely representing a scepter. The figure is dressed in a long-sleeved tunic which is belted at his waist. His vestments are complete with a cloak buttoned up below his neck, covering his shoulders, falling over his back, and reaching below his knees. This relief can be dated within the second and first centuries B.C.E. ${ }^{37}$ The presence of the characteristic tiara with the top pointed downwards and the neck and ear coverings turned up, which is reminiscent of the coinage of Xerxes, Abdissar, and Baydād, enables us to narrow its date down to the second century B.C.E. This type of tiara has been attested only in the territories of Fars, present-day northern Iraq, and southeastern regions of Anatolia. It is possible that this particular headdress originated in Fars. Under the rulers who used the title fratarakā, Achaemenid traditions were kept alive in Fars. ${ }^{38}$ For this reason, it would have been rather odd for these rulers to adopt the new custom of wearing the soft tiara from Sophene or Adiabene, i.e., the territories that were culturally and politically peripheral to Fars.

\footnotetext{
${ }^{26}$ This idea could be tentatively suggested on the analogy of Media Atropatene and Armenia (where Arsacid dynastic lines were introduced in the first century C.E.). See Frye (1984: 239-40).

${ }^{27}$ For instance, Grabowski (2011: 133) suggests the appointment of Hyspaosine in Characene (as a governor) by Antiochos IV as a direct parallel for Abdissar and Adiabene.

${ }^{28}$ Sullivan (1990: 105-12).

${ }^{29}$ De Callataÿ (1996: 135-36).

${ }^{30}$ De Callataÿ (1996: fig. 1.1a-d, 1.2a).

${ }^{31}$ De Callataÿ (1996: fig. 2.1a, 2.2a, 2.2b).
}

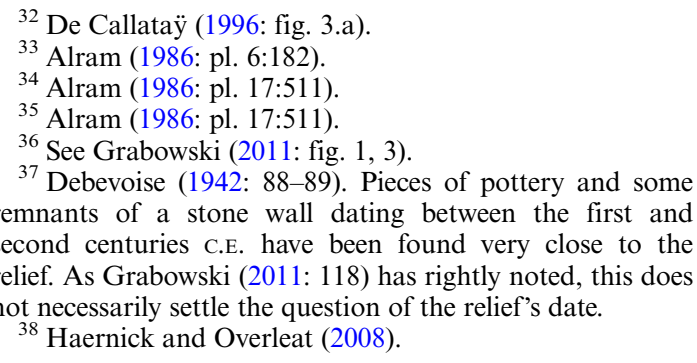

${ }_{33}^{32}$ De Callatä̈ (1996: fig. 3.a).

Alram (1986: pl. 6:182)

35 Alram (1986. pl. 17.511)

${ }^{36}$ See Grabowski (2011: fig. 1, 3).

${ }^{37}$ Debevoise (1942: 88-89). Pieces of pottery and some remnants of a stone wall dating between the first and (o.E. have been found very close to the not necessarily settle the question of the relief's date. ${ }^{38}$ Haernick and Overleat (2008). 

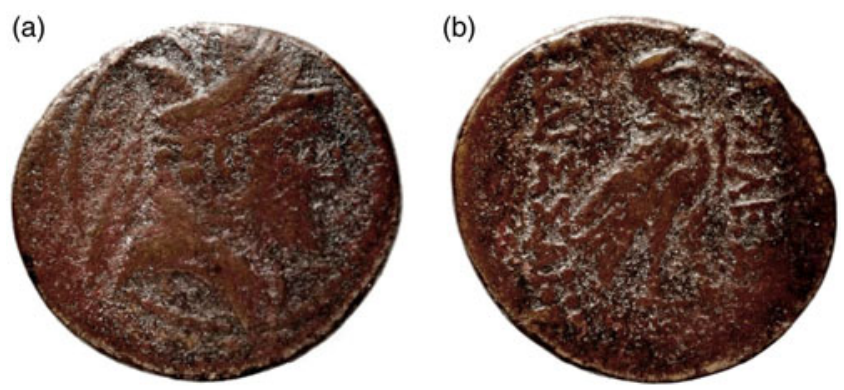

Fig. 1 Coin of Abdissar, type 1, courtesy of Bibliothèque nationale de France
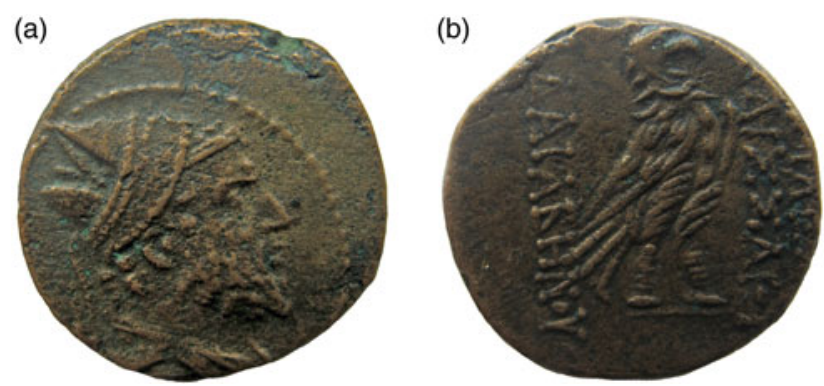

Fig. 2 Coin of Abdissar, type 2, courtesy of F. de Callataÿ, Bibliothèque royale de Belgique, Inv. II, 81.698
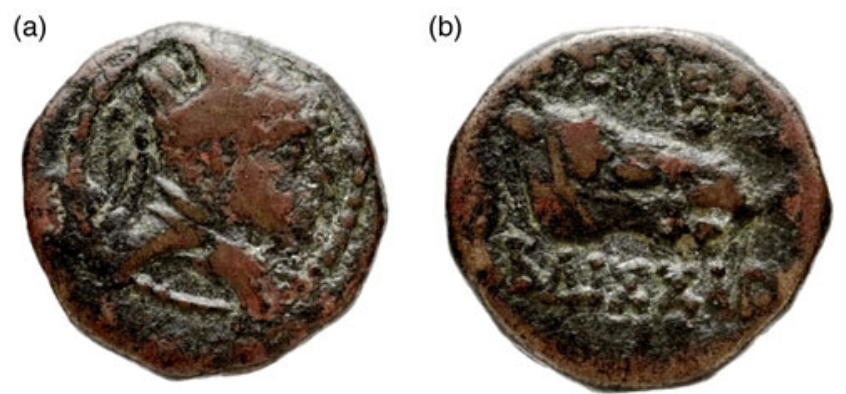

Fig. 3 Coin of Abdissar, type 3, Bibliothèque nationale de France

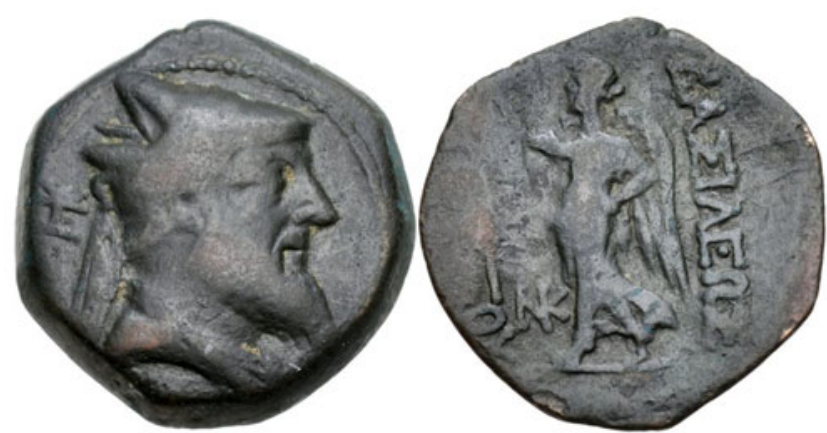

Fig. 4 Coin of Xerxes, courtesy of the Classical Numismatic Group, Inc., www.cngcoins.com 

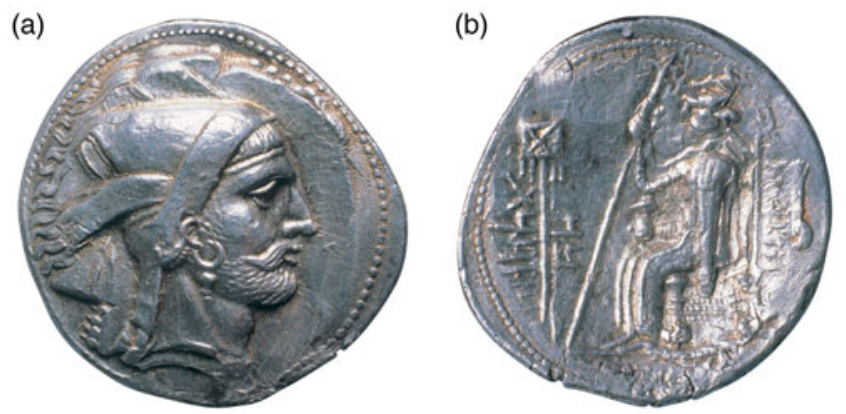

Fig. 5 Coin of Baydad, courtesy of Staatliche Münzsammlung München

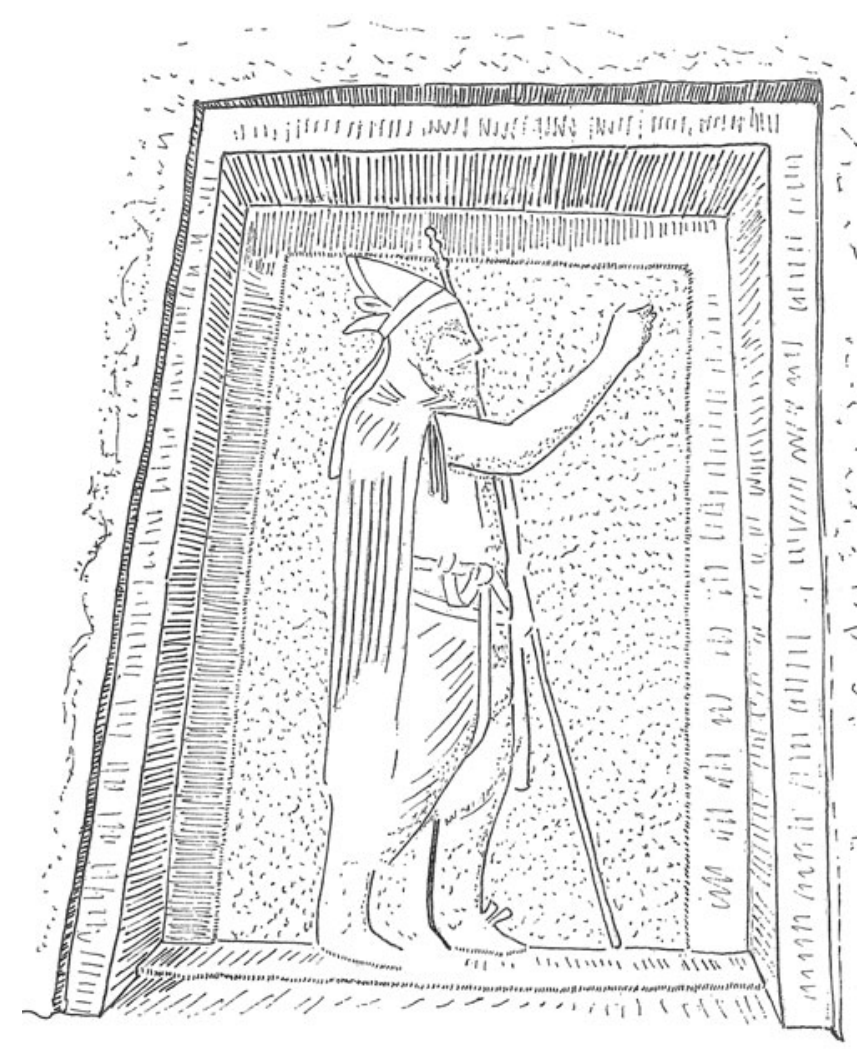

Fig. 6 Drawing of the Batas Herir relief by H. von Gall (R.M. Boehmer, H. von Gall 1973, p. 68, Abb. 2), courtesy of Deutsches Archäologisches Institut

Maciej Grabowski has noticed a similarity between Abdissar's image on coinage and the image of an unknown ruler from Batas-Herir. In both cases, the images show male figures in conical tiaras tied with a broad diadem, and with the neck covers, and ear covers in the case of Batas-Herir, turned up. The two figures have short cropped beards and short hair visible under their headdresses. According to Grabowski, this may indicate that Abdissar and the figure from the rock-carved relief at BatasHerir are one and the same. ${ }^{39}$ This hypothesis may be considered plausible from an iconographic as well as a chronological perspective. This new manner of wearing the soft tiara originated in the late third to the early second century B.C.E. It can be found on the coins issued under the rulers of

${ }^{39}$ Grabowski (2011: 132-34). 


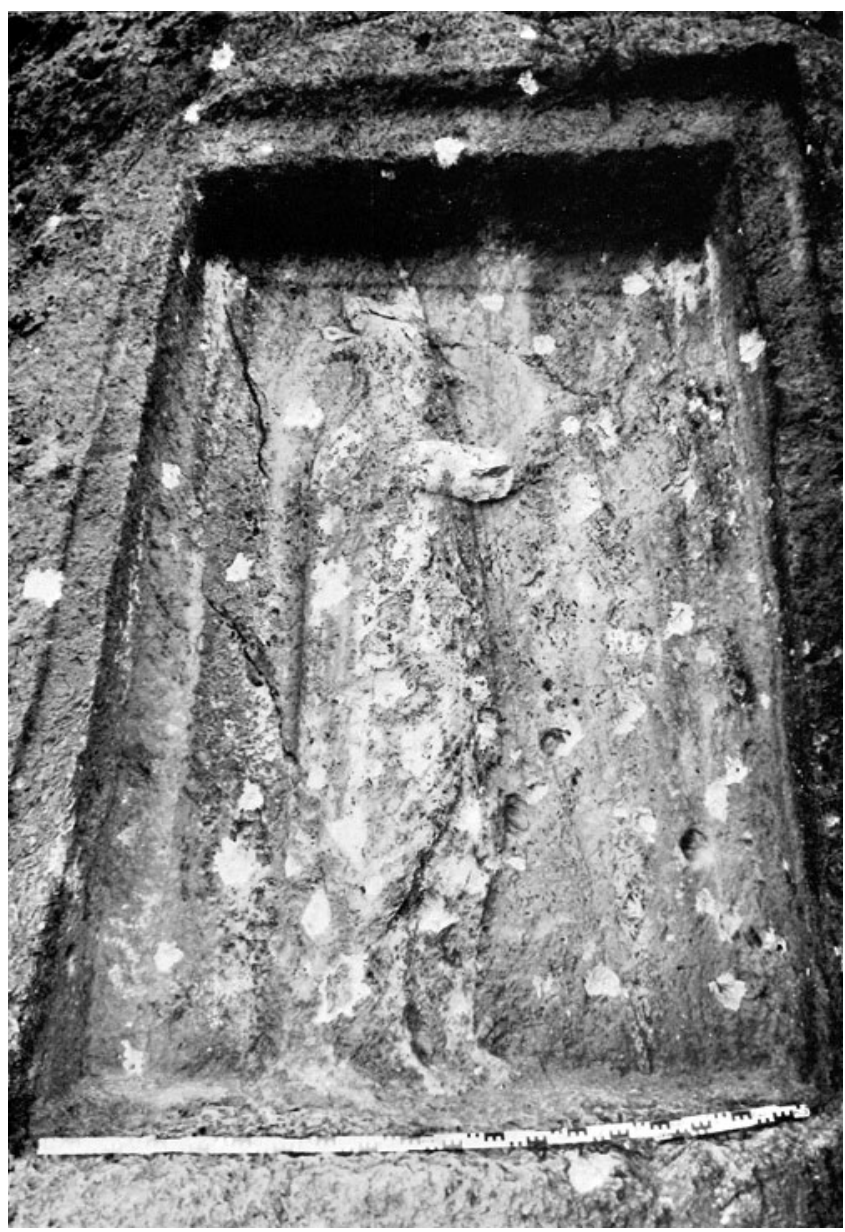

Fig. 7 The Batas Herir relief (R.M. Boehmer, H. von Gall 1973, Tafel 28), courtesy of Deutsches Archäologisches Institut

the first half of the second century B.C.E. (Xerxes, Abdissar, and Baydād). Considering the distinctive tiara depicted in the relief of Batas-Herir, it would likewise be datable to the first half of the second century B.C.E., i.e., during Abdissar's reign. Moreover, the geographical location of this site (northern Mesopotamia) appears to support Grabowski’s proposition.

The reverse of types I and II of Abdissar's coinage display an eagle, facing right, clearly standing upon the ground. Conversely, the motif of an eagle perched on a thunderbolt appeared on the coins of the Ptolemaic rulers, beginning from Ptolemaios I. ${ }^{40}$ The raptor's image faces the left or right, with its wings closed or outstretched. ${ }^{41}$ The same motif also appears on Seleucid coinage, though definitely not as frequently. ${ }^{42}$ In terms of similarities to Abdissar's coins, it is significant that the eagle was featured in Ptolemaic and Seleucid coinage during the first half of the second century B.C.E., as in

\footnotetext{
${ }^{40}$ It is frequently argued that the motif of the Hellenistic royal eagle may have originated as the winged sun-disc in Egypt. The winged disc was indeed associated with supreme god and kingship in Hittite, Assyrian, and Achaemenid iconography. See Shahbazi (1994) and Reade (2009: 253-54, fig. 14).

${ }^{41}$ Svoronos (1904: Pl. 2b 25-35, 3a 24-25, 31-32, 3b 1317,5 b 25-26, 6b 16-18, 21-27, 7a10b).

42 The image of an eagle appears on the coins of Achaios (220-215 B.C.E.) (Gardner 1878: 30, pl. X 3), Seleukos IV
}

(187-175 в.C.E.), Antiochos IV (175-164 в.C.E.) (Gardner 1878: 38, pl. XII 11-13), Alexander Balas (150-145 B.C.E.) (Gardner 1878: 51, pl. XV 4), Demetrios II (145-140, 129126/5 в.C.E.) (Gardner 1878: 58, 76, pl. XVII 7, XXI 1), Cleopatra (126/5-123 в.C.E.) and Antiochos VIII (126/5-96 B.C.E.) (Gardner 1878: 85, pl. XXIII 2), Antiochos VIII (Gardner 1878: 88, 90, pl. XXIII 8, XXIV 4), Antiochos IX (114/113-95 в.C.E.) (Gardner 1878: 91, pl. XXIV 7-8). 
the coins of Ptolemaios III, ${ }^{43}$ Ptolemaios IV, ${ }^{44}$ and Ptolemaios V, ${ }^{45}$ as well as Seleukos IV and Antiochos IV. ${ }^{46}$ As Grabowski argues, the coinage of a Seleucid king may have been a direct inspiration for Abdissar. ${ }^{47}$ With all the chronological, political, and geographical aspects taken into account, and especially considering the distinct similarity of the eagle imagery on the coins of Antiochos IV and Abdissar, it is reasonable to assume that the ruler of Adiabene adopted the raptor motif from the Seleucid king's coinage.

In the ancient Near East, the eagle may have carried an additional symbolic significance related to the Achaemenid dynasty. In his descriptions of the banners of Cyrus the Great (559-530 в.C.E.) (Xen. Kyr. 7.1.4) and Artaxerxes III (359-338 в.C.E.) (Xen. Anab. 1.10.12.), Xenophon mentions a golden eagle with outstretched wings. His account is confirmed by Curtius Rufus, who describes the golden eagle image adorning Dareios III's chariot (336-330 B.C.E.) (Curt. Anab. 3.3.16). Ancient historians' accounts are also confirmed by the archaeological evidence. It must be noted, however, that the bird may have been a falcon or some other raptor. The best known artifact bearing a bird motif as a royal emblem of a type mentioned in ancient sources is an Achaemenid faience tile from Persepolis depicting a falcon with outstretched wings. ${ }^{48}$ Images of prey birds (eagles or falcons) on flags can be seen on the reliefs of Persepolis, ${ }^{49}$ the Duris vase from the Louvre. ${ }^{50}$ In addition, a falcon or eagle appears on an Achaemenid gold earring found in western Anatolia. ${ }^{51}$ A similar depiction of a raptor can also be seen on a gold disc and plaque from the Oxus hoard. ${ }^{52}$ Another noteworthy object is a gold aigrette from the territory of Iran that portrays a falcon or eagle, shown with its wings closed, catching a snake. ${ }^{53}$ It is dated to the fourth century B.C.E. ${ }^{54}$ It is unclear if this royal emblem should be identified as a falcon or an eagle. The situation is further complicated by Curtius Rufus, who, in his description of Dareios III's vestments, mentions two golden hawks (accipitres) adorning the king's purple tunic (Curt. Anab. 3.3.17). King Cyrus the Great's dream about Dareios, the son of Hystaspes (later known as King Dareios the Great), suggests that the Persians perceived the raptor to be a symbol of authority. As recounted by Herodotus, King Cyrus saw Dareios with a pair of wings spreading out from his shoulders, one of which cast a shadow over Asia (Hdt. 1.209). This vision is clearly symbolic of the future reign of Dareios I and his elevation to the royal throne, which accounts for the motif of a raptor with outstretched wings. This motif appears both in Achaemenid-era iconography and ancient literary sources.

The origin of the eagle motif on the reverse of Ptolemaic and Seleucid coinage is also worth mentioning. Originally, the coins featured Zeus enthroned with an eagle on his right hand and a scepter in his left, such as on the coins of Ptolemaios I ${ }^{55}$ and Seleukos I, ${ }^{56}$ in imitation of the coinage minted in the name of Alexander the Great. ${ }^{57}$ Chronologically later, a sole eagle standing on the thunderbolt, the symbol of Zeus, appeared. The absence of the chief Olympic deity and the prominence of the eagle is an element of a policy designed to legitimize the authority of the new dynasties ruling over the states that succeeded the former Achaemenid Empire. For the Macedonians and Greeks, the eagle and the thunderbolt continued to symbolize Zeus. However, the Egyptians and Asians may have viewed these as symbols of royal power, as in the iconography of the Achaemenid dynasty. The Hellenistic coinage featured the two variations of the eagle image, with outstretched or closed wings. As the above-mentioned examples of artifacts from the Old Persian period demonstrate, both of these variations existed from as early as Achaemenid rule.

Types I and II of Abdissar's coins were very likely influenced by the coins of Seleukos IV and Antiochos IV. However, the eagle appears to have been a symbol of royal authority rather than a

\footnotetext{
${ }^{43}$ Svoronos (1904: pl. 46a; Tal 2012 : fig. 14.17).

${ }^{44}$ Svoronos (1904: pl. 47a 4-14, 47b).

${ }^{45}$ Svoronos (1904: pl. 48a 1-5, 7-14, 48b, 49a; 49b 17, 1920, 22, 24-28; 50a, 1-2, 4-11, 14-15; 50b).

${ }^{46}$ Gardner (1878: 38, pl. XII 11-13).

${ }^{47}$ Grabowski (2011: 132).

${ }^{48}$ Sekunda (1992), see photo on page 12. Sekunda is certainly correct in his interpretation of this image as a falcon.

${ }^{49}$ Olbrycht (2004: 91). A depiction of the Achaemenid standard attached to a spear can also be found on the reverse of Ptolemaios I's early coin, which was minted at
}

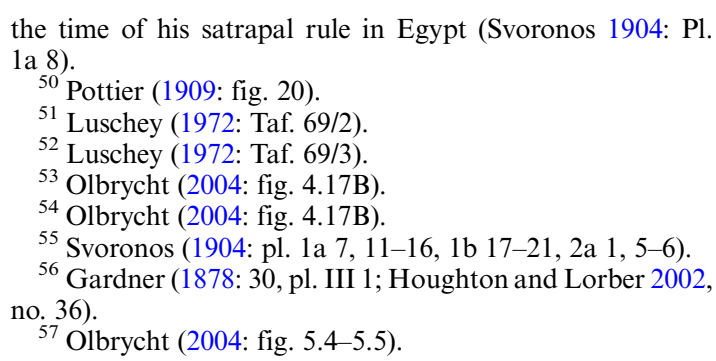

1a 80 ).

${ }^{51}$ Luschey (1972: Taf. 69/2)

${ }^{52}$ Luschey (1972: Taf. 69/3)

${ }_{54}^{53}$ Olbrycht (2004: fig. 4.17B)

Olbrycht (2004: fig. 4.17B)

${ }^{56}$ Gardner (1878: 30, pl. III 1; Houghton and Lorber 2002,

${ }^{57}$ Olbrycht (2004: fig. 5.4-5.5). 
deliberate reference to the Seleucid dynasty. This supports Grabowski's argument that, based on the coinage of his reign and the rock-cut relief at Batas-Herir, Abdissar was the first king of Adiabene and the founder of the independent kingdom. ${ }^{58}$

The third type of Abdissar's coinage is marked with a horse's head. ${ }^{59}$ The head of a horse with a pair of horns appeared on the obverse of Seleukos I's coinage (311-281 B.C.E.). ${ }^{60}$ It can also be found on the reverse of Antiochos I's coinage (281-261 в.C.E.), with the king's diademed and horned head on the obverse. ${ }^{61}$ Likewise, the head of a horse with a pair of horns is depicted on the reverse of issues of Seleukos II (226/225-223 в.C.E.) ${ }^{62}$ and Antiochos III (223-187 в.C.E.). ${ }^{63}$ Furthermore, a small horse's head appears on the reverse of the coin of Seleukos IV (187-175 в.C.E.), where the ruler is shown on the left-hand side sitting on Apollo's omphalos with a bow in his left hand and an arrow in his right hand. ${ }^{64}$ The coinage of Seleukos IV indicates that a horse's head was part of the imagery of Seleucid coins in the early second century B.C.E., which may have influenced Abdissar's coinage.

The image of a horse on Seleucid coinage was not limited to a depiction of the animal's head. The reverse of the coinage of Seleukos I bears a depiction of a horned rider on a galloping horned horse and, ${ }^{65}$ on the reverse, the front half of a galloping horse. ${ }^{66}$ The coinage of Antiochos I also contained images of a horned horse ${ }^{67}$ and the front half of a galloping horse. ${ }^{68}$ In turn, the coins of Antiochos II (261-246 B.C.E.) show the image of galloping Dioscuri, ${ }^{69}$ whereas the coinage of Seleukos II depicts a winged horse (Pegasus) on the reverse ${ }^{70}$ and the sole figure of the horned king as a horseman on the obverse. ${ }^{71}$ The other coins of Seleukos represent a mounted cavalryman piercing an enemy with his lance. ${ }^{72}$ The coinage of the same king also features representations of a horse alone ${ }^{73}$ or with a shield placed underneath. ${ }^{74}$ The horned horse, ${ }^{75}$ as well as the image of the king as a charging horseman, ${ }^{76}$ can be seen on the coins of Antiochos III. Some of his coinage also depicted images of a horse alone ${ }^{77}$ or a horse or mare with a foal. ${ }^{78}$

Regarding the significance of the horse motif in Seleucid coinage, and indirectly in the third type of Abdissar's coinage, it should be noted that the equestrian representations had already appeared on Macedonian or, to put it more generally, Balkan coins. A horseman with two spears appears on Bisaltae coins, dated to 500-480 B.C.E., which acted as an inspiration for the coins of Alexander I, the Macedonian king. ${ }^{79}$ The same image appears on issues of the later ruler, Archelaos (413-399 B.C.E.).$^{80}$ The fact that the image's arms are identical to those of a regular Persian cavalryman of the period, with the customary possession of two spears (Xen. Kyr. 4.3.9; De re eq. 12.12.), cannot be a coincidence, given the fact that the territory of contemporary Macedonia was part of the Achaemenid Empire. ${ }^{81}$ Consequently, horse motifs on Seleucid coinage can be traced back to Achaemenid-era Iran. ${ }^{82}$ This conjecture is substantiated by the small bronze coin of Ptolemaios I, minted prior to Ptolemaios' assumption of the royal title. The coin's obverse bears an image of a

${ }^{58}$ Grabowski (2011: 133-34).

${ }^{59}$ De Callataÿ (1996: fig. 3.a).

${ }^{60}$ Houghton and Lorber (2002: no. 1).

${ }^{61}$ Houghton and Lorber (2002: no. 323).

${ }^{62}$ Houghton and Lorber (2002: no. 775).

${ }^{63}$ Houghton and Lorber (2002: no. 1182).

${ }^{64}$ Le Rider (1965: Pl. LXII 2).

${ }^{65}$ Houghton and Lorber (2002: no. 203).

${ }^{66}$ Houghton and Lorber (2002: no. 269). An interesting equestrian image can be found in the Navkur plain located near the villages of Khanes and Bavian. It presents a rider (with a spear) in profile moving right. The rider has a short beard, and wears a (perhaps diademed) headgear (cylindrical but a little broader at the top) with flaps (likely wide ribbons) at the sides and back of the head. For this relief, see Debevoise (1942: 94); Mathiesen (1992b: 184); and especially Reade and Anderson (2013: 97-118), who recently argued for three distinctive stages of carving: neoAssyrian, Hellenistic (in commemoration of Alexander's victory at the nearby Gaugamela), and finally the Parthian phase.
${ }^{67}$ Houghton and Lorber (2002: no. 471).

${ }^{68}$ Houghton and Lorber (2002: no. 425).

${ }^{69}$ Houghton and Lorber (2002: no. 565, 567).

${ }^{70}$ Houghton and Lorber (2002: no. 771).

${ }^{71}$ Houghton and Lorber (2002: no. 709).

72 Houghton and Lorber (2002: no. 767).

${ }^{73}$ Houghton and Lorber (2002: no. 710).

${ }^{74}$ Houghton and Lorber (2002: no. 716).

${ }^{75}$ Houghton and Lorber (2002: no. 1182).

76 Houghton and Lorber (2002: no. 1259).

${ }^{77}$ Houghton and Lorber (2002: no. 1264).

${ }^{78}$ Houghton and Lorber (2002: no. 1269).

${ }^{79}$ Olbrycht (2004: 92, fig. 2.13).

${ }^{80}$ Olbrycht (2004: 93).

81 Olbrycht (2010: 343-45); Sekunda (2010: 447-48).

82 The horse and horseman motifs on Seleucid coins, including the dioscurii imagery, may have been construed by the Macedonians and Greeks differently than in Asia. In the latter case, some motifs from earlier Achaemenid iconography would have very likely played a much more prominent role. 
galloping horse, while the reverse depicts a globe-tipped spear with a standard positioned horizontally to the spear, ${ }^{83}$ reminiscent of the Achaemenid standards described above.

The importance of the horse in Iranian culture in both ancient and modern times is enormous. The animal's presence on coins (as a horned horse's head, or as the entire figure of a horned riding horse) distinguishes it as something divine. In this context, it is here worth recalling Curtius Rufus' account of the marching order of the troops of Dareios III: the holy fire was carried first, then came a column of magi and young men, who were followed by a white carriage dedicated to "Jupiter" and drawn by white horses and, finally, by the grandest horse called "the horse of the Sun" (Curt. Anab. 3.3.11). In addition, Dareios' prophetic dream of Alexander entering the city of Babylon on horseback foreshadowed the fall of the Achaemenid Empire (Curt. Anab. 3.3.3). Therefore, the equestrian image on Abdissar's coins could be regarded as a symbol of royal authority recognized by the deity, but also a visible sign of the power and wealth represented by the figures of the horsemen, at that time the superior military force in the East.

Monobazos I. Another king of Adiabene whose numismatic image is known to us is Monobazos. The attribution of this coin to Adiabene has never been in doubt; we know of two rulers of Adiabene bearing this name who reigned in the first century C.E., and no other Hellenistic or Parthian ruler has ever been known to bear this name outside the Adiabene dynasty. ${ }^{84}$ This of course leads us to another question: which of the two kings of Adiabene (Monobazos I or Monobazos II) is depicted on the coin?

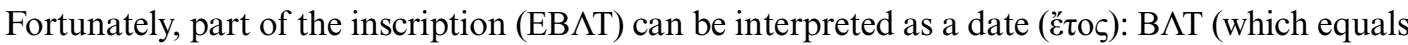
332). ${ }^{85}$ If the Seleucid era is used, the coin can be dated to $20 / 21$ C.E.; if, however, it is the Parthian era, then the date is $84 / 85$ C.E. ${ }^{86}$ The first date would fit the reign of Monobazos I, who most likely reigned from 5 B.C.E. to 30 C.E. ${ }^{87}$ The second date would exclude Monobazos I; it would be possible (but not definite) that the date might work for Monobazos II, whose reign is attested through scattered references in ancient sources which describe him as being alive and active on the international scene from 55 to 70 C.E. ${ }^{88}$ By $84 / 85$ C.E. Monobazos II might still have been alive but there is no evidence to confirm this. Therefore, it appears to be safer to base our dating on positive data. We know that the first date fits Monobazos I perfectly, while for Monobazos II the second date is only a possibility. ${ }^{89}$ However, the deciding argument concerns the use of eras. While the Parthian era was mainly used by the court and the Parthian administration in Iran, the Seleucid era appears to have been more widespread, especially in Hellenistic and Parthian Mesopotamia; it was used in Hatra, Assur and most likely in Nineveh. ${ }^{90}$ All things considered, the coin was probably minted in 20/21 C.E. and should be attributed to Monobazos I, the father of Izates II (the famous convert to Judaism), and not to Monobazos II, the son of Monobazos I and the brother and successor of Izates II.

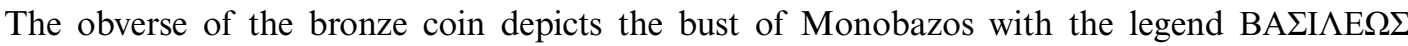
MONOBAZOY (Fig. 8). The king is shown facing right, with a protruding nose and a pointed beard. The ruler wears a tiara crowned with four spikes, adorned with three round appliqué motifs in the middle. The lower part of the tiara is encircled by a wide headband that should be identified as a diadem. Short cropped hair reaching down to the king's neck can be seen under the tiara. There is a large earring in his ear. The ruler is dressed in a cloak clasped at his right shoulder. The reverse depicts an ear of grain with the inscription EB $\Lambda \mathrm{T}$ (with two characters on either side) in

\footnotetext{
${ }^{83}$ Svoronos (1904: Pl. 1a 8).

${ }^{84}$ See Marciak (2014a: 233-46). Although the name itself is attested outside the Adiabene nobility, it appears as Munbaz in Rabbinic literature and as Manabaz in the Ashur inscriptions. See Jastrow (1975: 744); Aggoula (1985: 34-35. no. 12); and Beyer (1998: 13, no. 12). The name is widely considered to be of Iranian origin. It probably derives from Iranian mana and vazdah, meaning the proper name of the god (Vohu) Manah and permanence, respectively. See Marciak (2014a: 227), who relies on de
}

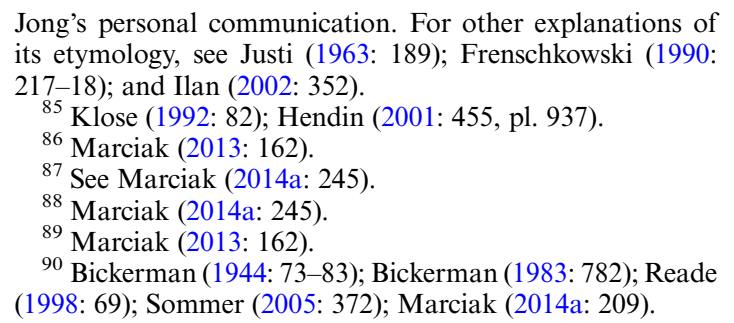
-18); and Ilan (2002: 352)

${ }^{86}$ Marciak (2013: 162).

${ }^{87}$ See Marciak (2014a: 245)

89 Marciak (2013: 162)

${ }^{90}$ Bickerman (1944: 73-83); Bickerman (1983: 782); Reade (1998: 69); Sommer (2005: 372); Marciak (2014a: 209). 
(a)

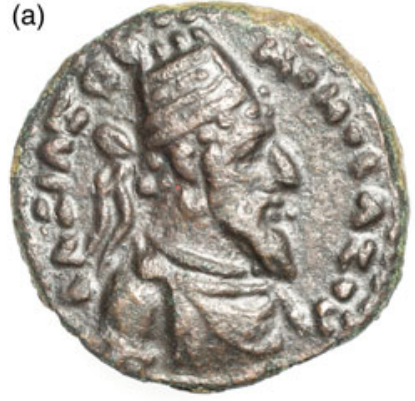

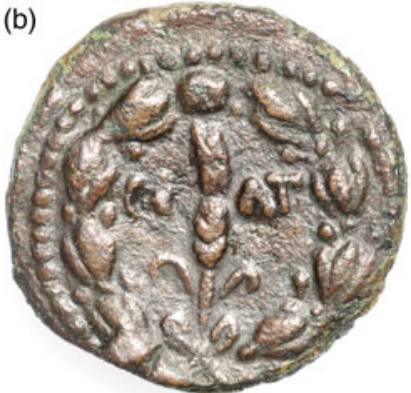

Fig. 8 Coin of Monobazos I, courtesy of Staatliche Münzsammlung München

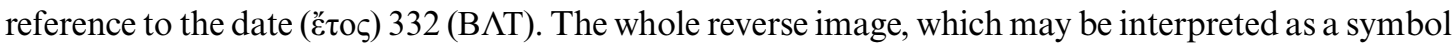
of prosperity and well-being, is encircled with a wreath. ${ }^{91}$

This characteristic "dentate" tiara is clearly reminiscent of the regalia of the rulers of Armenia, known in scholarly literature as the Armenian tiara. This headdress is typical of the Armenian coinage of the Late Hellenistic Period. ${ }^{92}$ The best known example of this motif (Fig. 9) is on the coins of Tigranes the Great (95-56 в.C.E.). ${ }^{93}$ Apart from the dentate upper part, the typical Armenian tiara had neck and ear coverings, ${ }^{94}$ which are missing on Monobazos' coin. The Armenian tiaras normally had five spikes, ${ }^{95}$ as is known from the extant iconography, but there is also some evidence of four- ${ }^{96}$ or seven-spiked tiaras. ${ }^{97}$ This type of tiara is found in images of Antiochos I (ca. 69-34 B.C.E.), the ruler of Commagene (Fig. 10). ${ }^{98}$ Interestingly, the abovementioned four-pronged Armenian tiara, the type shown on Monobazos' coin, can also be found on the recently identified bronze coins of Artaxias III (18-35 C.E.). ${ }^{99}$ Their obverse displays an image of a galloping horse, while a four-spiked Armenian tiara is depicted on the reverse (Fig. 11). ${ }^{100}$ The coins date back to the year 18 C.E., ${ }^{101}$ which means that they may have served as a direct inspiration for Monobazos' coinage.

The tiara of king Monobazos was certainly inspired by the Armenian model, but this particular headdress originated in Achaemenid-era Iran, not in Hellenistic Armenia. ${ }^{102}$ In fact, depictions of rulers wearing "dentate" crowns can be found in artifacts of the Achaemenid dynasty. ${ }^{103}$ The first known image of a "king of kings" with this type of crown is the relief of Dareios the Great (533485 в.C.E.) at Behistun (Fig. 12). ${ }^{104}$ The "dentate" crown can also be seen on coins showing the king as an archer (Fig. 13). ${ }^{105}$ In Olbrycht's opinion, Achaemenid tiaras may have been modeled in a similar fashion (a Persian king's tiara of this type is described in the Birds by Aristophanes; the Greek comedy-writer remarked that it resembled a cock's crest). ${ }^{106}$ Significantly, in his analysis

\footnotetext{
${ }^{91}$ Klose (1992: 82, coin no. 151).

92 The earliest attested examples of Armenian tiara imagery date from the early second century B.C.E., namely on King Zariadres' coin (attested around 189 B.C.E.), which some scholars believe to be a counterfeit, and the coin of Artaxias I (189-160 B.C.E.). The last Armenian coins depicting a ruler wearing the Armenian tiara are those from the reign of Tigranes V (6-12 C.E.) (Nercessian 1985: 4, 7, Pl. I, No. 8-9, Pl. II, No. 39). Representations of the Armenian tiara alone subsequently appeared on some Armenian and Roman coins (Krengel 2013: Abb. 1-8; Nercessian 1985, pl. II 40, 43). 22).

${ }^{93}$ Young (1964: 31); Nercessian (1985: 2, 5-6, Pl. I, No. 13-

${ }^{94}$ Nercessian (1985: 2).

95 According to Nercessian (1985: 2), the five spikes were one of the most important features of the Armenian tiara.

${ }^{96}$ Krengel (2013: Abb. 3-4, 6-7).
}

\footnotetext{
${ }^{97}$ The denarius featuring a seven-pronged Armenian tiara on the reverse was struck in honor of Tigranes III's (20 B.C.E.8 C.E.) elevation to the throne by Augustus in 20 B.C.E.

${ }^{98}$ Armenian tiaras can be seen on the coinage of Antiochos I and in the images of this king in the reliefs at Nemrud Dağ 1 and Seliq.

${ }^{99}$ Krengel (2013: Abb. 3-4, 6-7).

${ }^{100}$ Krengel (2013: Abb. 3-4, 6-7)

${ }^{101}$ Krengel (2013: 8-9).

102 Young (1964: 31).

${ }^{103}$ A kind of dentate crown can also be found in images of an Assyrian Ishtar. See, e.g., Reade (2009: 253, fig. 14), as well as Reade (1987). The origin and the historical development of this type of crown certainly requires further research with regard to this "Assyrian" trace, but it appears that Hellenistic images are directly derived from the Achaemenid heritage.

${ }^{104}$ Calmeyer (2001: fig. 13.a); Koch (1992, Abb. 5-7).

${ }^{105}$ Olbrycht (2004: 285)

${ }^{106}$ Olbrycht (2004: 285).
} 

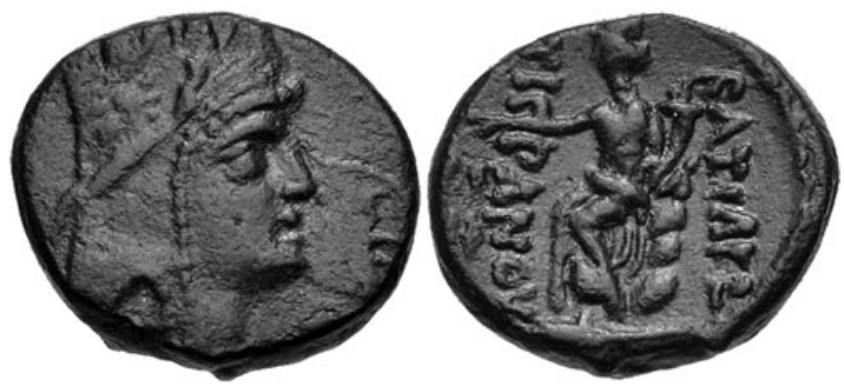

Fig. 9 Coin of Tigranes II, courtesy of the Classical Numismatic Group, Inc., www.cngcoins.com
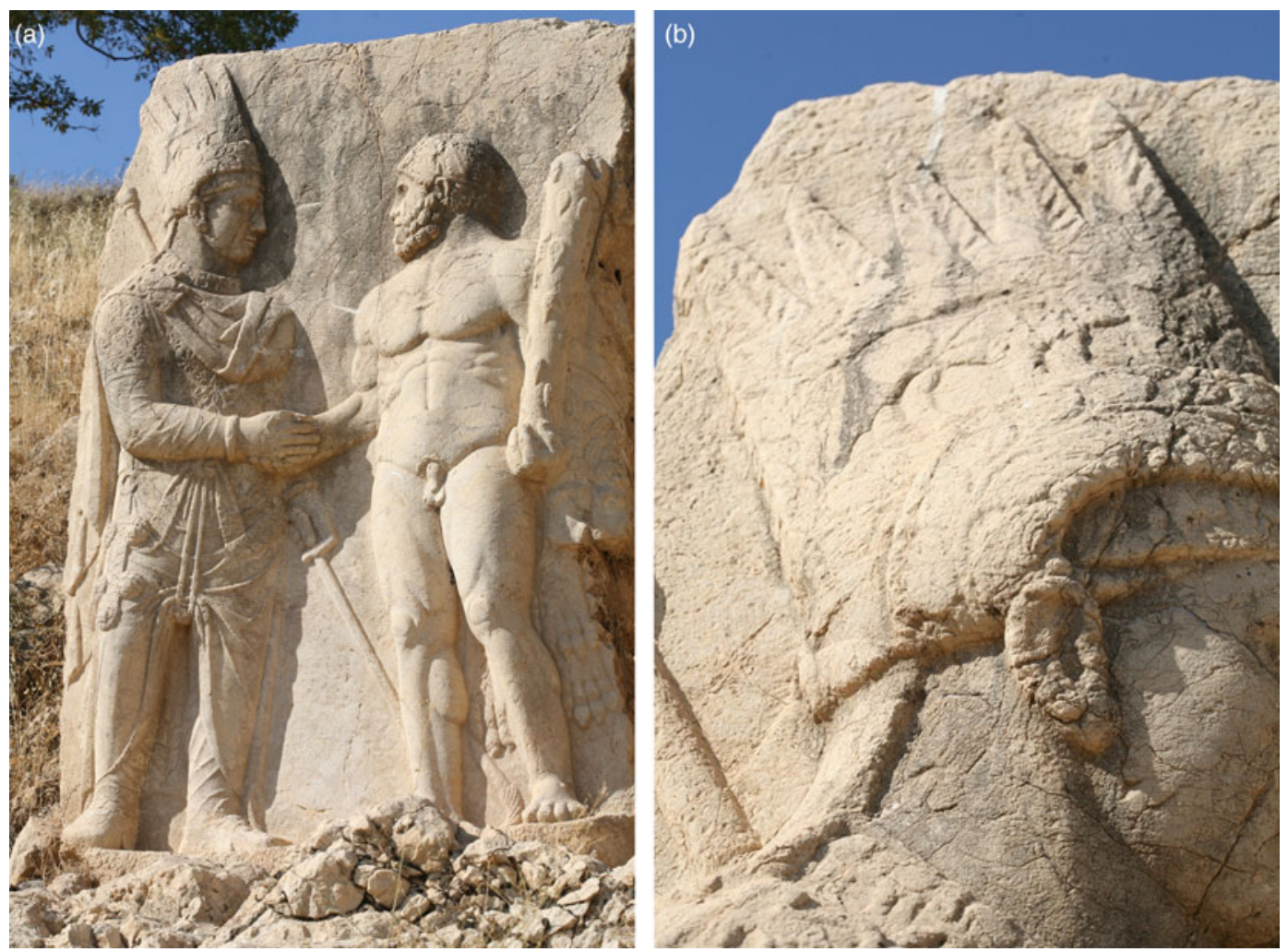

Fig. 10 Sculpture of Antiochos I of Commagene, courtesy of M.J. Olbrycht
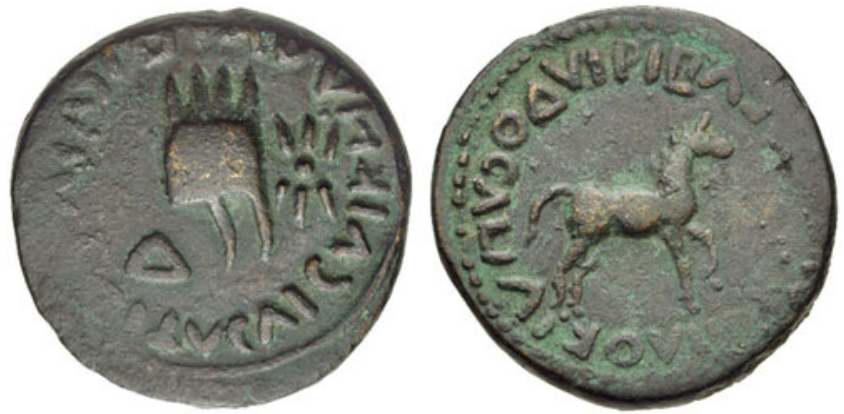

Fig. 11 Coin of Artaxias III, courtesy of the Classical Numismatic Group, Inc., www.cngcoins.com 


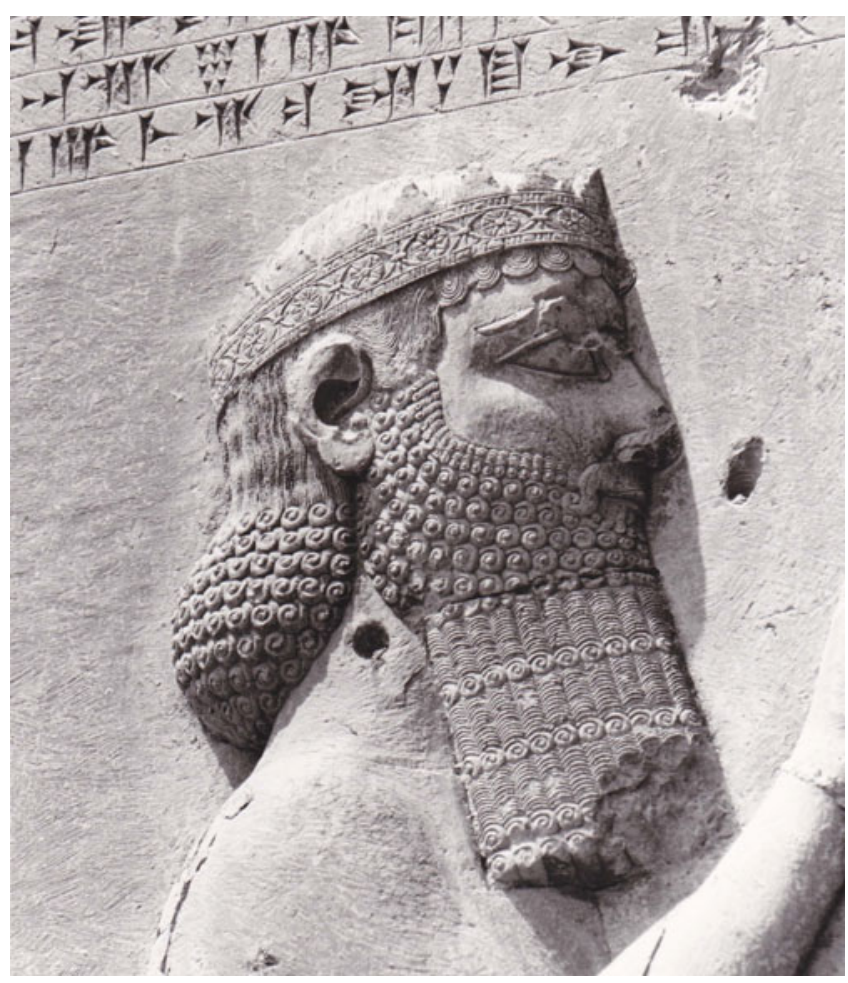

Fig. 12 Dareios I at Behistun, courtesy of H. von Gall
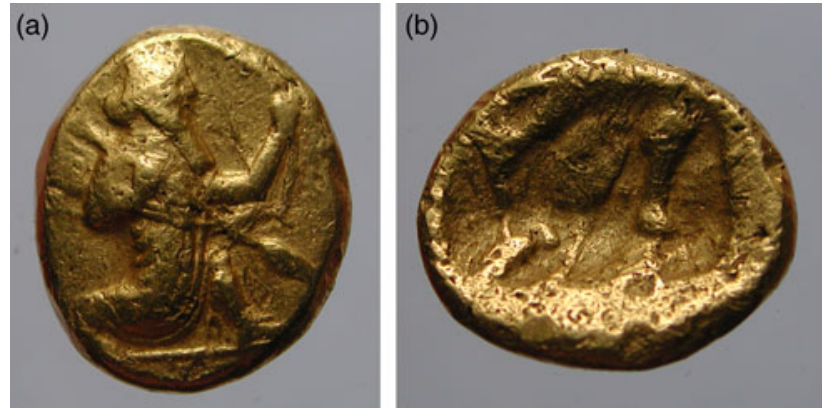

Fig. 13 Persian coin, courtesy of the Hutten-Czapski Museum in Kraków, coin no. MNK-VII-A-6444

of the images from Persepolis, M. Roaf observes that "dentate" crowns would have been worn by courtiers as well as the king. ${ }^{107}$ This remark might just as well be applied to the "dentate" tiara, even though no such representation has been confirmed during the reign of the Achaemenid dynasty. Following the fall of the Achaemenid Empire, the insignia of royal and satrapal authority, such as diadems and various types of tiaras, were adopted by the rulers of various successor states. One of such insignia, the "dentate" tiara, became part of the regalia of Armenian kings. However, the details of how this occurred remain unknown. Likewise, we do not know why King Monobazos was portrayed wearing a tiara that was clearly influenced by the Armenian type. Without additional historical sources, we are able to do little more than speculate. In the first century C.E., Adiabene reached the peak of its political power. To a certain extent, it temporarily supplanted Armenia as the prominent force in that area of the Near East (incidentally, according

${ }^{107}$ Roaf (1983: 131-33). 
to Josephus, Ant. 20:17-96, the acquisition of Nisibis by Adiabene under Izates II occurred at the expense of Armenia). Therefore, in practical terms, the adoption of the popular Armenian tiara may have been a propaganda maneuver to present Adiabene as a new regional power.

'tlw (Attalos). Another image of a king of Adiabene has been brought to light through excavations at Hatra. The ruins of the temple of Baal Shamin revealed a number of statues of kings and nobles who were depicted there as worshippers of the deity. ${ }^{108}$ One of the statues was completed with an inscription (Hatra inscription no. 21) which identifies the worshipper as 'tlw mlk' ntwn'šry'.109 The term 'tlw can be interpreted as the proper name of the worshipper who is presented as the king ( $m l k ')$ and also called $n t w n ' s ̌ r y{ }^{\prime} .110$

The proper name 'tlw has been vocalized as Ātal by Altheim and Stiehl, ${ }^{111}$ and as 'Ațilu by Beyer. ${ }^{112}$ According to Lipiński, 'tlw from Hatra in fact goes back to a widespread Greek name, "A $\tau \tau \alpha \lambda \mathrm{o} \varsigma$ - Hatrene $t$ corresponds to Greek $\tau \tau$, and the final $\varsigma$ was not noted. ${ }^{113}$ The identification of $n t w n$ 'šry' aroused a great deal of scholarly discussion (concerning more its etymology than its historical identification), ${ }^{114}$ but it appears that a general consensus has recently been reached. The term can be interpreted as consisting of the following elements: natun, a participial form meaning "given"; 's $r$, the proper name of the goddess Ishtar; and $y$ ', a yud-gentilic closing the expression. ${ }^{115}$ Thus, the term ntwn 'sry' is an ethnicon and may be more closely identified thanks to the parallel epigraphic evidence. The name in question appears to be parallel to the Iranian renderings of the Greek name of Adiabene. ${ }^{116}$ That is to say, the trilingual inscription of Shapur I (on the walls of Ka'ba-ye Zardosht near Naqsh-e Rostam) lists countries under his power, including Adiabene. Interestingly, the Greek toponym 'A $\delta 1 \alpha \beta \eta v \eta$ was rendered into the Parthian and Middle-Persian languages as $n t w \check{s} r k n$ and $n w t h s ̌ t r k n$, respectively. ${ }^{117}$ According to Lipiński, nūn was confused with $w \bar{a} w$ in the Parthian inscription (which could easily happen in Aramaic scripts of the late Parthian period $^{118}$ ), and the correct spelling would be Ntnšrkn ( $w \bar{a} w$ would be only a mater lectionis). In turn, the Middle Persian spelling implies the same confusion of $w \bar{a} w$ with $n \bar{u} n$ and a metathesis of the letters $t n$, read as $w t .{ }^{119}$ Therefore, the Hatra name ntwn'šry' can be taken to mean "Adiabenean", and King 'tlw (Attalos) can be identified as a ruler of Adiabene.

The inscription on the 'tlw (Attalos) statue does not contain any dates, but we can infer some information from archaeological context. The statue was placed in the temple of Baal Shamin, which was built in 138 C.E. (inscription no. 272) and destroyed by the Sasanians in 238 C.e. ${ }^{120}$ Furthermore, because of stylistic similarities with the statue of Sanatruq II (see below), the date can be narrowed. Thus, two out of nine Hatra inscriptions (nos. 36 and 229) referring to the reign of Sanatruq II bear the dates 549 and 541, ${ }^{121}$ that is, in accordance with the Seleucid era, 237/238 C.E. and 231 C.E., respectively. ${ }^{122}$ This suggests that the reign of 'tlw (Attalos) can be more specifically placed in the first half of the third century C.E.

What can be said about the rule of 'tlw (Attalos)? The fact that foreign rulers contributed to the cult of Hatra clearly shows that this city played the role of a superregional sanctuary. ${ }^{123}$ Furthermore, the placement of the sculpture of 'tlw (Attalos) in a temple located in the territory

\footnotetext{
${ }^{108}$ For a good overview, see Dirven (2008).

109 Beyer (1998: 33).

${ }^{110}$ See Caquot (1952: 101); Altheim and Stiehl (1967: 264); Milik (1962: 52); Drijvers (1977: 824); Lipiński (1982: 11720); Beyer (1998: 33).

${ }_{111}$ Altheim and Stiehl (1967: 264).

112 Beyer (1998: 33).

${ }^{113}$ Lipiński (2015: 205).

${ }^{114}$ For various, but now outdated, interpretations see Huyse (1999b: 20). It was especially Milik's interpretation (1962: 52) that was widely followed by archaeologists (e.g. Mathiesen 1992: 214; Raschke 1978: 818, n. 722; Butcher 1991: 4; Hoover 2009: 161-68), though not by linguists.

${ }^{115}$ See Drijvers (1977: 824); Lipiński (1982: 117-20); and Beyer (1998: 33). This explanation may have been considered as having one difficulty: it uses a West-Aramaic
}

participial form for an area dominated by East-Semitic Aramaic dialects. However, the research of Zadok (1977: 127-30, 135-36) shows that the qatūl (qattūl) forms, though less frequent, appear in the Babylonian onomasticon. Consequently, their presence in Hatrene Aramaic can be seen as a remnant of archaic forms of Aramaic. For the implication of Zadok's research, see Lipiński (1982: 117-20).

${ }^{16}$ Huyse (1999b: 20); Marciak (2013: 169-72); Marciak (2014a: 219-21)

${ }^{117}$ Huyse (1999a: 115); Huyse (1999b: 20).

${ }_{118}$ Naveh (1972: 299); Lipiński (2015: 204).

${ }^{119}$ Lipiński (2015: 204-05).

${ }^{120}$ Drijvers (1977: 821); Teixidor (1967: 2).

${ }^{121}$ Beyer (1998: 38-39, 73); Sommer (2005 : 372).

${ }^{122}$ Sartre (2005: 346).

${ }^{123}$ Drijvers (1977: 824-25); Marciak (2014a: 221). 
of another kingdom (as rulers of Hatra already used the title of the king at that time ${ }^{124}$ ) also attests to the good relations and close cultural ties between the two kingdoms. Unfortunately, the reign of 'tlw is not attested in other sources, and consequently our knowledge of the reign of 'tlw (Attalos) remains very limited.

As for the statue (Fig. 14), it represents a standing figure of a bearded man wearing a high upright tiara, complete with a neck covering. ${ }^{125}$ The tiara is adorned with a diadem in the form of a wide headband decorated with rows of small pearls along the lower edge. The man's face has regular features: almond-shaped eyes, moustache ends pointed slightly upwards, and a fan-shaped beard. The king's neck is most probably adorned with a torques. He wears a richly decorated knee-length tunic with long sleeves and a broad ornamented belt around his waist, signifying his status and affluence. A narrower belt is used to fasten a sword to his left side. Over his tunic, he wears a longsleeved jacket unbuttoned on his chest, with wide, elaborately embroidered hems. Folds, but more likely trouser legs worn over tighter trousers, can be seen underneath his tunic. This specific garment was very closely connected with equestrian culture. Its original role was to protect the trousers during horse-riding (the aristocracy's trousers were often made from a very fine and delicate material). A similar piece of clothing is still used among cowboys and vaqueros in North and South America (English: "chaps"/Spanish: chaparreras). The king's right hand is raised in a gesture of greeting or adoration, while his left hand rests on the hilt of his sword.

The characteristic features of this imagery have their origins in Parthian art. This most notably includes the frontal representation of the figure, the manners of depicting texture and creases, and the proportions of the statue. ${ }^{126}$ Also, several elements of the regalia, such as the diademed tiara and the king's sword strapped to a belt, are typical of how Parthian rulers and the aristocracy were normally represented.

A high tiara with a diadem and neck covering also appears on the reverse of Vologases IV's coin (191-206/207 C.E.) (Sellwood type 84 ${ }^{127}$ ) and the obverse of the coins of Vologases/Valash V (206/ 207-221/222 C.E.) (Sellwood type 88 ${ }^{128}$ ). ${ }^{129}$ It may have also been depicted on a stele of Ardavan (Artabanos) IV (214-224 C.E.) at Susa, ${ }^{130}$ dating from 215 C.E. ${ }^{131}$ The relief shows a frontal representation of the ruler, rendering the view of any neck covering impossible. Tiaras with neck coverings, shown as part of an Oriental costume, can be found on the reverse of the coins of Septimius Severus that were minted in 195 C.E. (see below). The tunic, decorated with a lozengeshaped motif that is also present on the above-mentioned statue, is also part of the Elymaean relief at Bard-i Nishandeh, dating to the early third century C.E. ${ }^{132}$ The ruler at the center might have a tiara complete with a neck covering, but the condition of the relief prevents any definite identification. ${ }^{133}$

The gesture of greeting or adoration can be seen on a small bronze statuette from Shami, showing a male figure dressed in a long-sleeved tunic. ${ }^{134} \mathrm{He}$ is not wearing a jacket, but he has a mantle folded on his left shoulder. These garments suggest that the object may date to the Late Parthian period. An identical gesture is made by a man dressed in Iranian vestments depicted on the relief of Tang-i Sarvak I, as well as by an Iranian ruler, a figure seated on the throne, and six standing male figures portrayed in the second row in the central part of the relief at Tang-i Sarvak II. ${ }^{135}$ The Tang-i Sarvak relief complex is usually dated to the period between the first and early third century C.E. ${ }^{136}$

Similar imagery also appears in the art of Hatra. Statues of a male figure dressed in a long-sleeved tunic, without a jacket or tiara, and with his right hand in a gesture of greeting and his left resting on a sword, were prominent in the art of this important city. This is evident in the statues of unidentified offering-bearers, Abd-Agilu, ${ }^{137}$ and Abdsami, son of Sanatruq I. ${ }^{138}$ The decorative lozenge motifs on
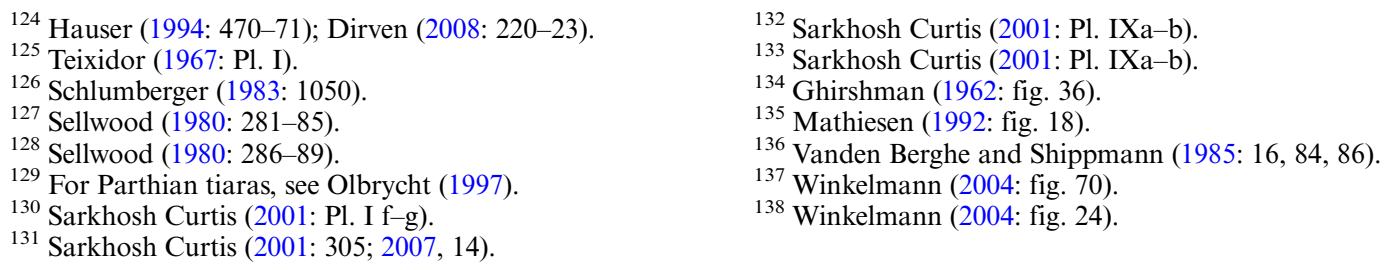


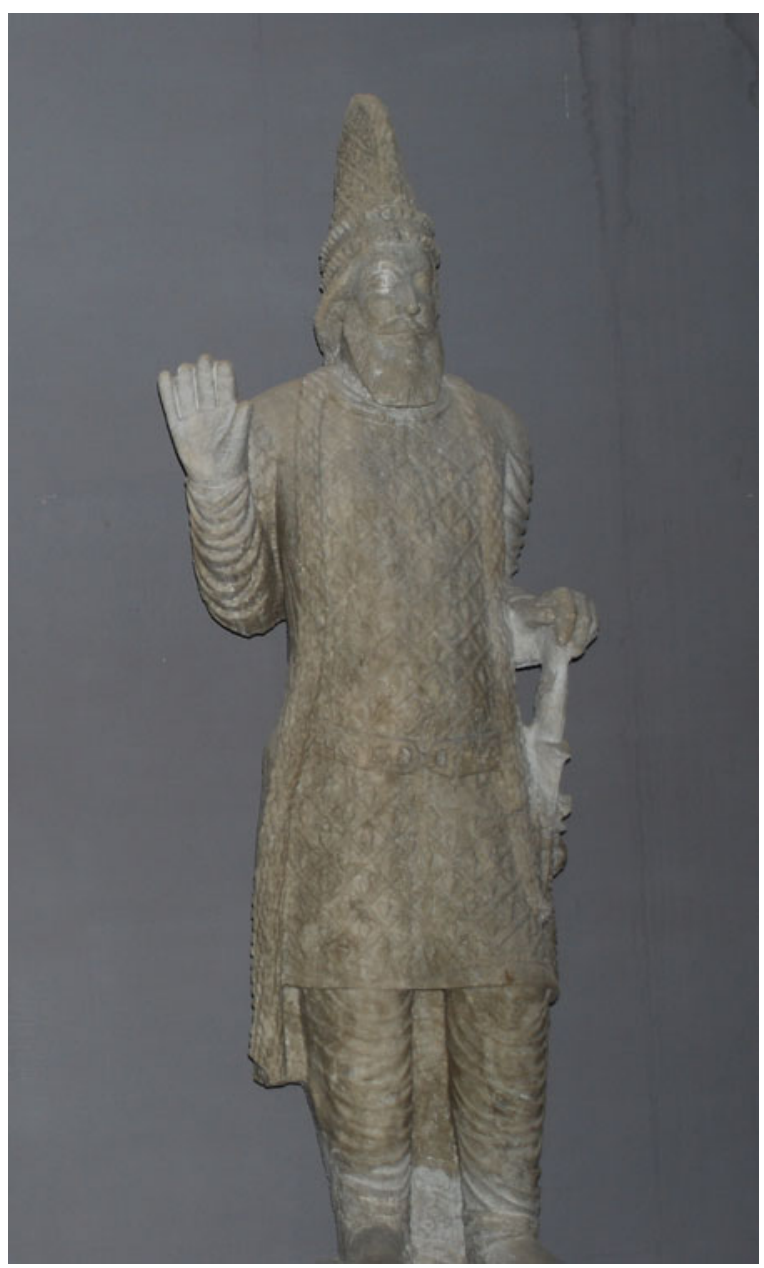

Fig. 14 Sculpture of 'tlw from Hatra, courtesy of D.C. Siebrandt, Deakin University

tunics can be found in the art of Hatra as well (notably on a statue of King Vorod [Orodes] ${ }^{139}$ and a statue of an unidentified ruler ${ }^{140}$ ). Images of tiaras in Hatra, such as the tiara of Sanatruq II, king of Hatra, ${ }^{141}$ and the head of a statue of an unidentified ruler, ${ }^{142}$ display a close resemblance to the tiara of the king of Adiabene.

The form and proportions of the statue show a close similarity to the other statues from Hatra. The shapes of the eyebrows, eyes, moustache, and, to a certain extent, the nose, are clearly evocative of the statue of Sanatruq II. Moreover, the position and the sculpting of the feet are almost identical to the Hatra king's image. ${ }^{143}$ The belts of the two figures deserve particular attention. Vesta Sarkhosh Curtis places them into the so-called Type $\mathrm{C}$ category, encompassing belts decorated with animal imagery, including various mythological creatures such as the griffin. ${ }^{144}$ These seem to have been fashionable garments in Hatra, even though the earliest known artifacts date back to the reign of Sanatruq II. ${ }^{145}$

An anonymous king of Adiabene: Pescennius Niger's ally? Another extant image of a king of Adiabene is believed to be depicted on the Roman coins of Septimius Severus, Roman Emperor from 193 to 211 C.E. In general, the coins under examination belong to the context of the domestic wars in the Roman

\footnotetext{
${ }^{139}$ Winkelmann (2004: fig. 2).

${ }^{140}$ Winkelmann (2004: fig. 12).

${ }^{141}$ Sommer (2003: fig. 28); Winkelmann (2004: fig. 33b).

${ }^{142}$ Ghirshman (1962: fig. 102).
}

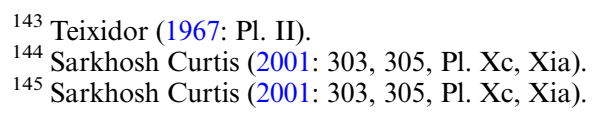


Empire from 193-194 C.E. (193 C.E. is widely known as the Year of the Five Emperors, as it witnessed the rise of as many as five claimants for the Roman throne: Pertinax, Didius Julianus, Pescennius Niger, Clodius Albinus and Septimius Severus). ${ }^{146}$ In particular, we owe their existence to the competition between Pescennius Niger and Septimius Severus. Pescennius Niger was the governor of Syria in 193 C.E. when he was proclaimed Emperor by eastern legions. ${ }^{147}$ Niger also managed to secure the support of the kingdoms of Edessa and Adiabene, as well as political support from Parthia. ${ }^{148}$ Eventually, it was Septimius Severus who prevailed over Niger and his supporters in a few stages. The decisive battle took place near Issos in 194 C.E. ${ }^{149}$ Niger was defeated and killed while attempting to flee to Parthia. Severus also turned against Niger's eastern supporters, including Edessa and Adiabene in 194-195 C.E. ${ }^{150}$ In 197 C.E., he invaded Parthia and sacked Ktesiphon, one of its capitals. ${ }^{151}$

In the aftermath of his success, Septimius Severus assumed several honorary titles (cognomina ex virtute), including PARTHICUS ADIABENICUS and PARTHICUS ARABICUS. These honorary titles were inscribed on milestones, ${ }^{152}$ coins ${ }^{153}$ and the famous arch of Septimius Severus which was erected in the Forum Romanum. ${ }^{154}$ These cognomina are frequently considered to refer to specific kingdoms-Adiabene on one hand, and Osrhoene or Hatra on the other. ${ }^{155}$ Consequently, it is tempting to think that the images on the epigraphic coins may represent specific rulers. ${ }^{156}$

Several issues of Septimius' coins can be distinguished in accordance with the numerals following the title IMPERATOR (IMP). The cognomina PARTHICUS ADIABENICUS and PARTHICUS ARABICUS appear on the coins belonging to the issues marked by IMP IIII (struck in 194-195 C.E.), IMP V (minted in 195 C.E.), IMP VI (195 C.E.) and IMP VII (struck in 195 C.E.). ${ }^{157}$ However, images of the two captives appear only on the IMP IIII and IMP V issues. ${ }^{158}$

It is the IMP V issue which is known for having the highest number of coins bearing the images of the two captive Oriental rulers (Figs. 15-16). This issue includes silver denarii struck by the mint of Rome in the name of Septimius Severus. The denarii bear a depiction of the emperor's laureate head, facing right, and the legend L SEPT SEV PERT AVG IMP V on the obverse. ${ }^{159}$ At the center of the reverse, a tropaion is shown as a symbol of the emperor's military triumph, with figures of sitting and shackled men in Iranian vestments to the right and left. Both of them wear long-sleeved tunics, belts around their waists, trousers, and mantles buttoned up below the neck. Each one has one leg tucked up and back, and the other one is held loosely in front. The scene includes the following legend: PART ARAB PART ADIAB COS II P P.

Two basic variations of the reverse can be distinguished, each with two sub-variants differing only in the precision of the image, depending on the presence or absence of the tiara upon the heads of the two figures. In variant I, (Figs. 15-16) the figure to the right of the tropaion wears no headdress, except for a diadem. Conversely, the man sitting on the left wears a high tiara, complete with neck, and perhaps also ear, coverings. This may suggest a difference in how the two men were meant to be portrayed and, as a result, allows us to identify them as distinct and separate figures. However, the other variant (Figs. 17-18) depicts them as basically identical: both wear diademed tiaras with neck coverings, contradicting the individualization of their respective images.

\footnotetext{
${ }^{146}$ For the historical context, see Hasebroek (1921: 50-81); Magie (1950: 669-73, 1538-42); Ziegler (1964: 129-32); Platnauer (1965: 74-98); Birley (1988: 108-20); Butcher (2003: 48); Sommer (2005: 239-40, n. 58).

${ }^{147}$ Hasebroek (1921: 73); Magie (1950: 669-70); Ziegler (1964: 129); Platnauer (1965: 76, 78-80).

${ }^{148}$ Hasebroek (1921: 73); Magie (1950: 672, 1541); Sommer (2005: 240); Ziegler (1964: 129-31).

${ }^{149}$ Platnauer (1918: 152); Hasebroek (1921: 61); Magie (1950: 1539-40); Platnauer (1965: 91).

${ }^{150}$ Hasebroek (1921: 75); Fluss (1923: 1960); Magie (1950: 1541); Platnauer (1965: 91, 93).

${ }^{151}$ Hasebroek (1921: 110-15); Platnauer (1965: 114-12); Birley (1988: 129-35); Hauser (2013: 121): 197 and 199 C.E.; Isaac (2013: 24): 197/198 C.E.
}

\footnotetext{
${ }^{152}$ See Murphy (1945: 80-87).

${ }^{153}$ See Mattingly and Sydenham (1936: 60, 66, 94-99).

${ }^{154}$ For the arch, see Brilliant (1967: especially 92-95 and 172-82) and Bonanno (1976: 143-46).

${ }^{155}$ See Bayer (1734: 165); Hasebroek (1921: 79-81); Günther (1922: 121); Chaumont (1987: 437-39); Hauser (1998: 516); Ross (2001: 48); Sommer (2005: 240); Isaac (2013: 25); Luther (2015: 286).

${ }^{156}$ See Reade and Anderson (2013: 113, fig. 60).

${ }^{157}$ Mattingly and Sydenham (1936: 96-99). See also Magie (1950: 1541); and Platnauer (1918: 150-51).

${ }_{158}$ Mattingly and Sydenham (1936: 96-98). See also Magie (1950: 1541); and Platnauer (1918: 150-51).

${ }^{159}$ Mattingly and Sydenham (1936: no. 690 a-c, no. 696).
} 

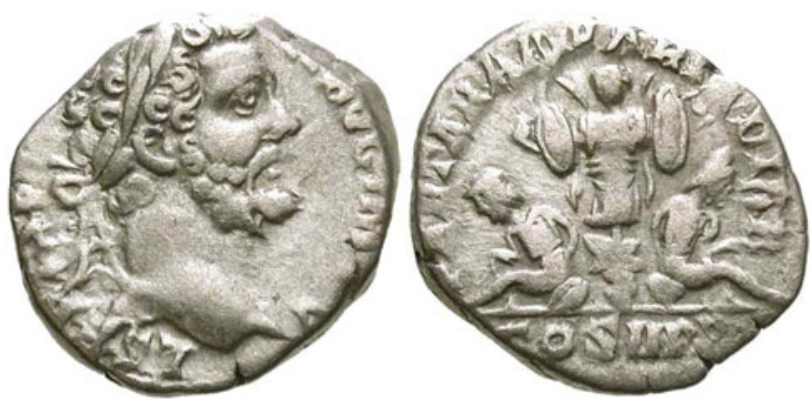

Fig. 15 Septimius Severus' coins, variant I, courtesy of Forum Ancient Coins
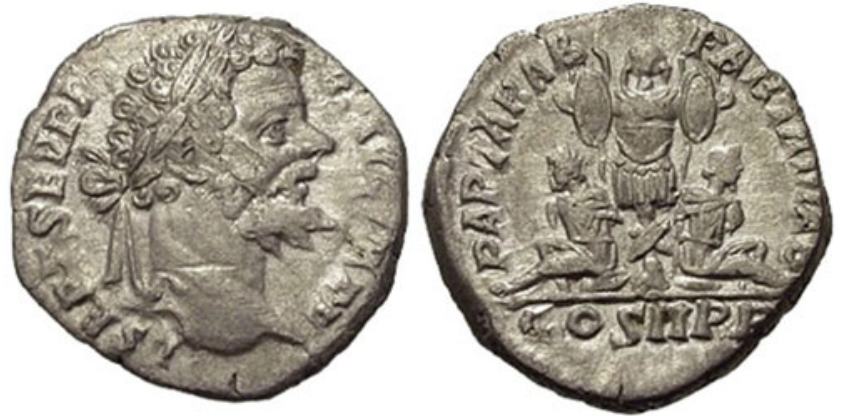

Fig. 16 Septimius Severus' coins, variant I, courtesy of Forum Ancient Coins

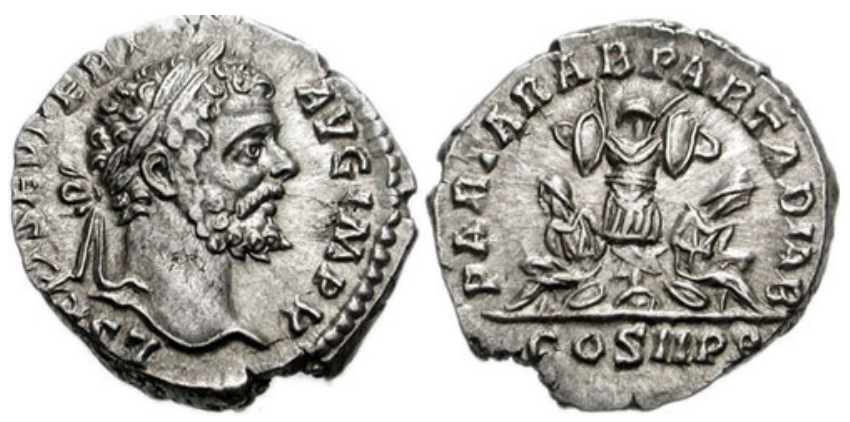

Fig. 17 Septimius Severus' coins, variant II, courtesy of the Classical Numismatic Group, Inc., www.cngcoins.com

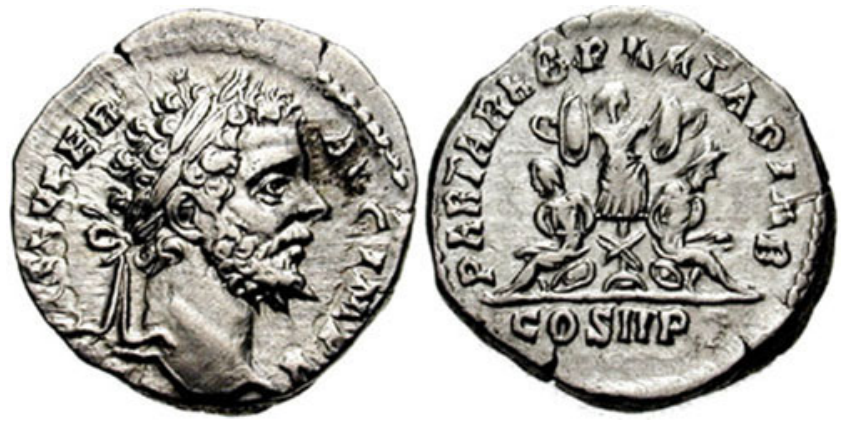

Fig. 18 Septimius Severus' coins, variant II, courtesy of the Classical Numismatic Group, Inc., www.cngcoins.com 
The reverse inscription clearly refers to Septimius Severus' campaigns in the East against the Adiabeneans and Arabs. Upon a closer examination of the images of the Oriental rulers, it is difficult to identify their ethnic identity based on their garments. The minters of the coin probably did not intend for such an identification. The reverse was only intended to show a stereotypical Roman vision of an Oriental man. The trousers and long-sleeved tunic were elements of a typical garment worn by the inhabitants of the Imperium Parthicum, as well as those from Edessa, Adiabene, Hatra, and some other states under the influence of Iranian culture. In effect, tiaras and diadems, worn together or separately, were a common part of the regalia of the Eastern rulers as well as the Oriental aristocracy.

\section{Summary}

This paper offers the first ever discussion of all extant images of Abdissar, Monobazos I and 'tlw (Attalos) of Adiabene. Abdissar's coins represent stylistic features which allow us to date them to the first half of the second century B.C.E. This in turn means that Abdissar was king of Adiabene before the advent of Parthian supremacy in Mesopotamia. Furthermore, stylistic features of Abdissar's coinage (the inscription and the images of an eagle and a horse) clearly served to emphasize the divine character of his royal power. Thus, Abdissar can be interpreted as the first ruler of Adiabene to assume the title of king and become independent in the context of the collapse of Seleucid domination in Mesopotamia. Furthermore, it appears that the same kind of headgear is depicted both on Abdissar's coins and in the Batas Herir monument, which strengthens Grabowski's identification of the Batas Herir figure as that of Abdissar.

Concerning the only extant coin of Monobazos I, its stylistic features clearly reflect the spirit of his time by showing the prosperity and rising political significance of the kingdom of Adiabene in the first half of the first century C.E. As far as the sculpture of King 'tlw is concerned, the stylistic features and historical context of the artefact suggest good political relations and close cultural ties between the kingdoms of Adiabene and Hatra in the first half of the third century c.E.

Lastly it is argued that the images of Oriental kings, known as "seated captives", on the coins of Septimius Severus (with the inscriptions ARAB ADIAB) do not depict any particular Oriental rulers (of Edessa, Hatra, or Adiabene), but are merely stereotypical images of what the Romans considered typically Oriental royal outfits.

\section{Bibliography}

Aggoula, B. 1985. Inscriptions et graffites Arameens d'Assour. Napoli.

Alram, M. 1986. Nomina propria iranica in nummis. Materialgrundlagen zu den iranischen Personennamen auf antiken Münzen, Iranisches Personennamenbuch IV. Wien.

Altheim, F. and R. Stiehl 1967. Die Araber in der alten Welt, B. 4. Berlin.

Barish, D. 1983. Adiabene: Royal Converts to Judaism in the First Century C.E.: A Study of Sources, Cincinnati (Diss.).

Bayer, T.S. 1734. Historia Osrhoene et Edessena, ex numis illustrate. Sankt Petersburg.

Bedoukian, P.Z. 1985. Coinage of the Armenian Kingdoms of Sophene and Commagene. Los Angeles.

Ben-Ami, D. and Y. Tchekhanovetz. 2011a. Has the Adiabene Royal Family "Palace" Been Found in the City of David? Pp. 231-39 in K. Galor and G. Avni (eds.), Unearthing Jerusalem. 150 Years of Archaeological Research in the Holy City. Winona Lake, IN.

2011b. The Lower City of Jerusalem on the Eve of Its Destruction. 70 CE: A View from Hanyon Givati. Bulletin of the American Schools of Oriental Research 364: 61-85.

Beyer, K. 1998. Die aramäischen Inschriften aus Assur, Hatra und dem übrigen Ostmesopotamien: (datiert 44 v. Chr. bis 238 n. Chr.). Göttingen.

Bickerman, E. 1944. Notes on Seleucid and Parthian Chronology. Berytus 8: 73-83.

1983. Time-Reckoning. pp. 778-91 in E. Yarshater (ed.), The Seleucid, Parthian and Sasanian Periods (CHI, vol. 3.2). Cambridge.

Bieberstein, K. and H. Bloedhorn. 1994. Jerusalem: Grundzüge der Baugeschichte vom Chalkolithikum bis zur Frühzeit der osmanischen Herrschaft, B. 3. Wiesbaden.

Birley, A. 1988. The African emperor: Septimius Severus. London.

Bonanno, A. 1976. Portraits and Other Heads on Roman Historical Relief up to the Age of Septimius Severus. Oxford.

Brilliant, R. 1967. The Arch of Septimius Severus in the Roman Forum. Rome. 
Butcher, K. 1991. Natounia on the Kapros: Coinage of a Lost Assyrian City. Numismatic Circular 99: 4. 2003. Roman Syria and the Near East. California, CA.

Callataÿ, F. de 1996. Abdissarès L'Adiabénien Iraq 58: 135-45.

Calmeyer, P. 2001. Crown i. In the Median and Acheamenid Periods, Encyclopædia Iranica (www.iranica.com).

Canepa, M. 2007. Review of Margherita Facella, La dinastia degli Orontidi nella Commagene ellenistico-roman, Pisa, 2006. Bryn Mawr Classical Review 2007.01.21.

Caquot, A. 1952. Nouvelles Inscriptions Arameenes de Hatra. Syria 29 : 89-118.

Chaumont, M.L. 1987. Un document méconnu concernant 1'envoi d'un ambassadeur parthe vers Septime Severe (P. Dura 6oB). Historia 36: 422-47.

Colpe, C. 1974. Die Arsakiden bei Josephus. Pp. 97-108 in O. Betz, K. Haacker, M. Hengel (eds.), JosephusStudien. Untersuchungen zu Josephus, dem antiken Judentum und dem Neuen Testament, Otto Michel zum 70. Geburtstag gewidmet. Göttingen.

Dąbrowa, E. 1983. La politique de l'état parthe à l'égard de Rome-d'Artaban II à Vologèse I (ca 11 -ca 79 de n.e.) et les facteurs qui la conditionnaient, Kraków.

2011. The Arsacid Empire. Pp. 164-86 in T. Daryaee (ed.), The Oxford Handbook of Iranian History. Oxford.

Debevoise, N.C. 1938. A Political History of Parthia. Chicago.

— 1942. The rock reliefs of ancient Iran. Journal of Near Eastern Studies 1: 76-105.

Delitzsch, F. 1887. The Royal Court of Adiabene. Expositor 36: 130-40.

Dignas, B. and E. Winter. 2007. Rome and Persia in Late Antiquity: Neighbours and Rivals. Cambridge.

Dillemann, L. 1962. Haute Mésopotamie orientale et pays adjacents. Contribution à la géographie historique de la région du Ve siècle avant l'ère chrétienne au VIe siècle de cette ère. Paris.

Dirven, L. 1999. The Palmyrenes of Dura-Europos: a Study of Religious Interaction in Roman Syria. Leiden.

- 2008. Aspects of Hatrene religion: A Note on the Statues of Kings and Nobles from Hatra. Pp. 209-46 in T. Kaizer (ed.), The Variety of Local Religious Life in the Near East in the Hellenistic and Roman Periods. Boston-Leiden.

Dodgeon, M.H. and S.N.-C. Lieu. 1991. The Roman Eastern Frontier and the Persian Wars: 363-628 AD: A Narrative Sourcebook. London.

Drijvers, H.J.W. 1977. Hatra, Palmyra und Edessa: Die Städte der syrisch-mesopotamischen Wüste in politischer, kulturgeschichtlicher und religionsgeschichtliche Beleuchtung. ANRW 2/8: 799-906.

Eiland, M.L. 1998. Parthians and Romans at Nineveh. Pp. 55-68 in E. Dąbrowa (ed.), Ancient Iran and the Mediterranean World, Electrum 2. Kraków.

Facella, M. 2006. La dinastia degli Orontidi nella Commagene ellenistico-romana. Pisa.

Fluss, M. 1923. L. Septimius (13) Severus. Realencyclopädie II A2: 1940-2002.

Fowler, R. 2010. King, Bigger King, King of Kings: Structuring Power in the Parthian World. Pp. 57-77 in T. Kaizer and M. Facella (eds.), Kingdoms and Principalities in the Roman Near East. Stuttgart.

Frenschkowski, M. 1990. Iranische Königslegende in der Adiabene: zur Vorgeschichte von Josephus, "Antiquitates" XX, 17-33. Zeitschrift der Deutschen Morgenländischen Gesellschaft 140/2: 213-33.

Frye, R.N. 1984. The History of Ancient Iran. München.

Gardner, P. 1878. Catalogue of Greek Coins. The Seleucid King of Syria. London.

Gawlikowski, M. 2010. Fifty Years of Polish Research in Palmyra 1959-2009. Warszawa.

Ghirshman, R. 1962. Persian Art 249 BC-AD 651, the Parthian and Sassanian Dynasties. New York.

Grabowski, M. 2011. Abdissares of Adiabene and the Batas-Herir Relief. Światowit. Annual of the Institute of Archaeology of the University of Warsaw 9: 117-40.

Greatrex, G. and S.N-C. Lieu. 2002. The Roman Eastern Frontier and the Persian Wars-Narrative. SourcebookPart II AD 363-630. London.

Günther, A. 1922. Beiträge zur Geschichte der Kriege zwischen Römern und Parthern. Berlin.

Haerinck, E. and B. Overlaet. 2008. Altar Shrines and Fire Altars? Architectural Representations on Frataraka Coinage. Iranica Antiqua 43: 207-33.

Hartmann, U. 2001. Das palmyrenische Teilreich. Stuttgart.

Hasebroek, J. 1921. Untersuchungen zur Geschichte des Kaisers Septimius Severus. Heidelberg.

Hauser, S. 1994. Chronologische und historischpolitische Untersuchungen zur östlichen Jazra in vorislamischer Zeit. Berlin (Diss.).

1998. Hatra und das Königreich der Araber. Pp. 493-528 in J. Wiesehöfer (ed.), Das Partherreich und seine Zeugnisse. Beiträge des Internationalen Colloquiums, Eutin (27.-30. Juni 1996). Stuttgart.

1998. Hatra und das Königreich der Araber. Pp. 493-528 in J. Wiesehöfer (ed.), Das Partherreich und seine Zeugnisse. Beiträge des Internationalen Colloquiums, Eutin (27.-30. Juni 1996). Stuttgart.

- 2013. Where is the man of Hadr, who once built it and taxed the land by the Tigris and Chaboras? On the significance of the final siege of Hatra. Pp. 119-42 in L. Dirven (ed.), Hatra: Politics, Culture and Religion between Parthia and Rome. Stuttgart.

Hendin, D. 2001. Guide to Biblical Coins. New York. 
Hoover, O. 2009. Camels of Natounia. Schweizerische numismatische Rundschau 88: 161-68.

Houghton, A. and C. Lorber. 2002. Seleucid Coins: A Comprehensive Catalogue: Part I: Seleucus I through Antiochus III. New York.

Huyse, Ph. 1999a. Die dreisprachige Inschrift Šābuhrs I. an der Ka`ba-i Zardušt ( ̌̌KKZ), B.1. London. 1999b. Die dreisprachige Inschrift Šäbuhrs I. an der Ka'ba-i Zardušt ( ̌̌KZ), B.2. London.

Ilan, T. 2002. Lexicon of Jewish Names in Late Antiquity. Part I: Palestine 330 BCE-300 CE, Tübingen.

Isaac, B. 2013. Against Rome and Persia. From Success to Destruction. Pp. 23-32 in L. Dirven (ed.), Hatra: Politics, Culture and Religion between Parthia and Rome. Stuttgart.

Jacobs, B. 1994. Die Satrapienverwaltung im Perserreich zur Zeit Darius' III. Wiesbaden.

Jastrow, M. 1975. A Dictionary of the Targumim, the Talmud Babli and Yerushalmi, and the Midrashic Literature I Comp. by Marcus Jastrow; with an Index of Scriptural Quotations, Vols. 1-2. New York.

Jong, A. de. 2013. Hatra and the Parthian Commonwealth. Pp. 143-60 in L. Dirven (ed.), Hatra, Politics, Culture and Religion between Parthia and Rome. Stuttgart.

Justi, F. 1963. Iranisches Namenbuch. Hildesheim.

Kaizer, T. 2002. The Religious Life of Palmyra: a Study of the Social Patterns of Worship in the Roman Period. Oriens et Occidens 4. Stuttgart.

Kettenhofen, E. 1982. Die römisch-persischen Kriege des 3. Jahrhunderts n. Chr. nach der Inschrift Sãhpuhrs I. an der Kabe-ye Zartost ( SKZ). Wiesbaden.

Klose, D. 1992. Von Alexander zu Kleopatra. Herscherporträts der Griechen und Barbaren. München.

Koch, H. 1992. Es kündet Dareios der König... vom Leben im persischen Grossreich. Mainz/Rhein.

Krengel, E. 2013. Die erste armenische Münzprägung für Zenon/Artaxias aus Pontus. Jahrbuch für Numismatik und Geldgeschichte 63: 1-16.

Le Rider, G. 1965. Suse sous les Séleucides et les Parthes. Mémoires de la Mission Archéologique en Iran 38. Paris.

Lipiński, E. 1982. Le culte d 'Istar en Mésopotamie du Nord à l'époque parthe. Orientalia Lovaniensia Periodica 13: 117-24.

2015. Review of M. Marciak, 'Izates, Helena, and Monobazos of Adiabene: A Study on Literary Traditions and History'. The Polish Journal of Biblical Research 14: 201-07.

Luschey, H. 1972. Ein königliches Emblem. Archäologische Mitteilungen aus Iran 5: 257-60.

Luther, A. 2015. Das Königreich Adiabene zwischen Parthern und Römern. Pp. 275-99 in E. Baltrusch and J. Wilker (eds.), Amici-socii_clientes? Abhängige Herrschat im Imperium Romanum. Berlin.

Magie, D. 1950. Roman Rule in Asia Minor to the End of the Third Century after Christ. Princeton.

Marciak, M. 2011. Seleucid-Parthian Adiabene in the Light of Ancient Geographical and Ethnographical Texts. Anabasis. Studia Classica et Orientalia 2: 179-208.

2013. Natounisarokerta on the Kapros. New Numismatic Evidence from the British Museum Anabasis. Studia Classica et Orientalia 4: 160-78.

2014a. Izates, Helena, and Monobazos of Adiabene. A Study on Literary Traditions and History, Harrassowitz, Philippika 66, Wiesbaden.

- 2014b. The Cultural Environment of Adiabene in the Hellenistic, Parthian, and Sasanian Periods. In: Parthica. Incontri di culture nel mondo antico 16: 111-50.

Mathiesen, E.H. 1992. Sculpture in the Parthian Empire, a Study in Chronology. Aarhus.

Mattingly, H. and E.A. Sydenham. 1936. The Roman Imperial Coinage, Pertinax to Geta, vol. IV, part I. London. Milik, J.T. 1962. A propos d'un atelier monétaire d'Adiabene: Natounia. Revue Numismatique 4: 51-58.

Murphy, G.J. 1945. The Reign of the Emperor L. Septimius Severus from the Evidence of the Inscriptions. Philadelphia.

Nercessarian, Y.T. 1985. The Evolution of the Armenian Tiara. Armenian Numismatic Journal 11: 2-12.

Naveh, J. 1972. The North-Mesopotamian Aramaic script-type in the Late Parthian Period. Israel Oriental Studies 2: 293-304.

Notley, R. and J. García. 2014. Queen Helena's Jerusalem Palace-In a Parking Lot? Biblical Archaeology Review May/June 2014: 28-68.

Oates, D. 1968. Studies in the Ancient History of Northern Iraq. London.

Oates, D. and J. Oates. 1958. Nimrud 1957: The Hellenistic Settlement. Iraq 20: 114-57.

Olbrycht, M.J. 1997. Vardanes contra Gotarzes II. Einige Überlegungen zur Geschichte des Partherreiches ca. 40-51 n. Chr. Folia Orientalia 33: 81-100.

— 1998a. Parthia et ulteriores gentes. Die politischen Beziehungen zwischen dem arsakidischen Iran und den Nomaden der eurasischen Steppen. München.

1998b. Das Arsakidenreich zwischen der mediterranen Welt und Innerasien. Bemerkungen zur politischen Strategie der Arsakiden von Vologases I. bis zum Herrschaftsantritt des Vologases III. (50-147 n. Chr.). Pp. 113-59 in E. Dąbrowa (ed.), Ancient Iran and the Mediterranean World. Studies in Ancient History. Proceedings of an International Conference in Honour of Professor Józef Wolski, Held at the Jagiellonian University, Cracow, in September 1996. Kraków.

—2004. Aleksander Wielki i świat irański [Alexander the Great and the Iranian World]. Rzeszów. 
2010. Iran Starożytny. Pp. 27-285 in A. Krasnowolska (red.), Historia Iranu, ['Ancient Iran' in

A. Krasnowolska (ed.), The History of Iran]. Wrocław.

Pani, M. 1972. Roma e i re d'Oriente da Augusto a Tiberio (Cappadocia Armenia, Media Atropatene). Bari.

Platnauer, M. 1965. The life and Reign of the Emperor Lucius Septimius Severus. Rome.

Pottier, E. 1909. Douris. London.

Rajak, T. 1998. The Parthians in Josephus. Pp. 309-24 in J. Wiesehöfer (ed.), Das Partherreich und seine Zeugnisse, Beiträge des internationalen Colloquiums (Eutin 27.-30. Juni 1996). Stuttgart.

Raschke, M.G. 1978. New Studies in Roman Commerce with the East. Aufstieg und Niedergang der römischen Welt 2/9: 604-1361.

Reade, J. 1987. Was Sennacherib a feminist? Pp. 139-45 in J.-M. Durand (ed.), La Femme dans la Proche-Orient Antique. Paris.

1998. Greco-Parthian Nineveh. Iraq 60: 65-83.

2001. More about Adiabene. Iraq 63: 187-99.

2009. Fez, Diadem, Turban, Chaplet: Power-Dressing at the Assyrian Court. Pp. 239-64 in M. Luukko, S.

Svärd, R. Mattila (eds.), Of God(s), Trees, Kings, and Scholars: Neo-Assyrian and Related Studies in Honour of Simo Parpola. Helsinki.

Reade, J. and J.R. Anderson. 2013. Gunduk, Khanes, Gaugamela, Gali Zardak-Notes on Navkur and Nearby Rock-Cut Sculptures in Kurdistan. Zeitschrift für Assyriologie 103: 69-123.

Roaf, M. 1983. Sculptures and Sculptors at Persepolis. Iran 21: 1-164.

Ross, S.K. 2001. Roman Edessa: Politics and Culture on the Eastern Fringes of the Roman Empire, 114-242 CE. London.

Sarkhosh Curtis, V. 2001. Parthian Belts and Belt Clasps. Iranica Antiqua 36: 299-32.

2007. The Iranian Revival in Parthian Period. Pp. 7-25 in V. Sarkhosh Curtis (ed.), The Age of Parthians London.

Sartre, M. 2005. The Middle East under Rome. Cambridge, MA.

Schlumberger, D. 1983. Parthian Art. Pp. 1027-54 in: E. Yarshater (ed.), The Cambridge History of Iran Volume 3: The Seleucid, Parthian and Sasanid Periods, Part 2. Cambridge

Schottky, M. 1989. Media Atropatene und Gross-Armenien in hellenistischer Zeit. Bonn.

Schuol, M. 2000. Die Charakene: ein mesopotamisches Königreich in hellenistischparthischer Zeit. Oriens et Occidens 1. Stuttgart.

Sekunda, N. 1992. The Persian Army (560-330 B. C.). London.

2010: The Macedonian Army. Pp. 446-71 in J. Roisman and I. Worthington (eds.), A Companion to Ancient Macedonia. Blackwell Companions to the Ancient World. Malden, MA and Oxford.

Sellwood, D. 1980: Introduction to the Coinage of Parthia. London.

Shahbazi, A.Sh. 1994. Derafš. Encyclopedia Iranica 7: 312-15.

Sommer, M. 2003. Hatra. Geschichte und Kultur einer Karawanenstadt im römisch-partischen Mesopotamien. Meinz am Rhein.

2005. Roms orientalische Steppengrenze: Palmyra, Edessa, Dura-Europos, Hatra: eine Kulturgeschichte von Pompeius bis Diocletian. Stuttgart.

Sullivan, R.D. 1990. Near Eastern Royalty and Rome, 100-30 B.C. Toronto.

Svoronos, J.N. 1904. Ta Nomismata tou Kratous ton Ptolemaion. Athens.

Tal, O. 2012. Greek Coinages of Palestine. Pp. 252-74 in W. E. Metcalf (ed.), The Oxford Handbook of Greek and Roman Coinage. Oxford.

Teixidor, J. 1967. The Kingdom of Adiabene and Hatra. Berytus 17: 1-11.

Tromp, J. 2005. The Life of Adam and Eve in Greek: A Critical Edition. Leiden.

Vanden Berghe, L. and K. Shippmann. 1985. Les reliefs rupestres d' elymä̈de (Irān) de l'epoque parthe. Iranica Antiqua, Supplément III. Gent.

Vincent, L.-H. and A.M. Steve. 1954. Jerusalem de l'Ancien Testament: recherches d'archéologie et d'histoire, vol. 1: Archéologie de la ville. Paris.

Winkelmann, S. 2004. Katalog der parthischen Waffen und Waffenträger aus Hatra. in Materialen des SFB "Differenz und Integration" Heft IV, Katalog der parthischen Waffen und Waffenträger aus Hatra, Halle/Saale.

Wolski, J. 1976. Iran und Rom. Versuch einer historischen Wertung der gegenseitigen Beziehungen. Aufstieg und Niedergang der römischen Welt 2.9.1: 195-214.

1993. L'empire des Arsacides. Leuven.

Young, J.H. 1964. Commagenian Tiaras: Royal and Divine. American Journal of Archaeology 68/1: $29-34$.

Zadok, R. 1977. On West Semites in Babylonia During the Chaldean and Achaemenian Periods: an Onomastic Study. Jerusalem.

Ziegler, K.H. 1964. Die Beziehungen zwischen Rom und dem Partherreich; ein Beitrag zur Geschichte des Völkerrechts. Wiesbaden. 
Michał Marciak

Department of Ancient History and Oriental Studies

University of Rzeszów

Al. Rejtana 16C

35-310 Rzeszów

Poland

michal.marciak@gmail.com

Robert S. Wójcikowski

Institute of Archaeology

The Jagiellonian University

Gołębia 11 Str.

31-007 Kraków

Poland

nalecz1@interia.pl

صور لملوك حدياب: أدلة نقدية ونحتية

بقلم: مايكل مارسياك وروبرت الثة فوبية ونيكية

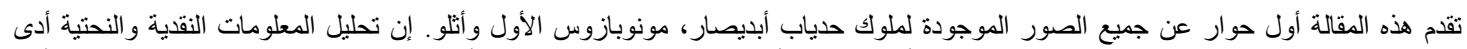

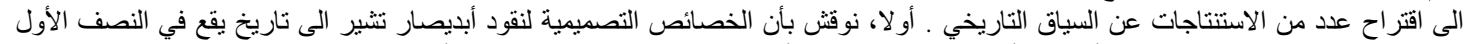

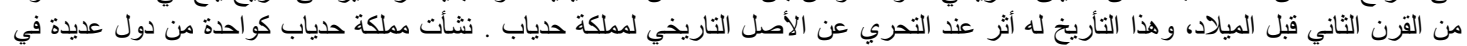

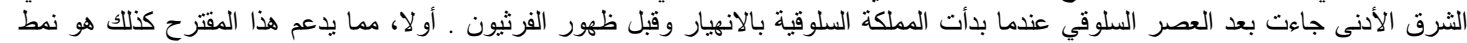

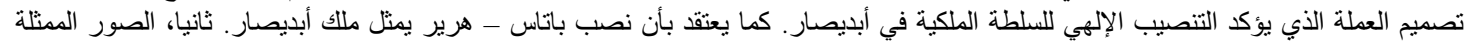

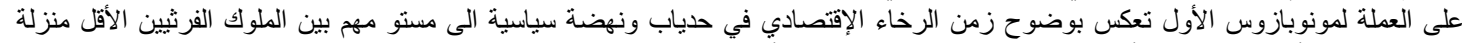

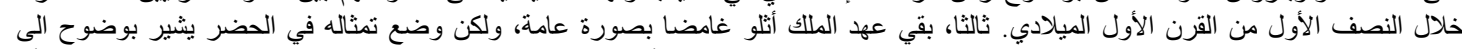

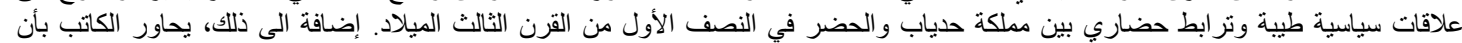

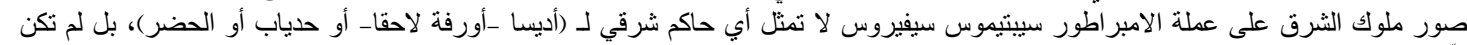
إلّا صور نمطية لما اعتبره الرومان نموذجا للملابس الملكية الثرقية. 